\title{
Evidence of overfishing of geoduck clam Panopea globosa from a length-based stock assessment approach
}

\author{
Marlene A. Luquin-Covarrubias ${ }^{1}$, Enrique Morales-Bojórquez ${ }^{\text {Corresp., }}{ }^{1}$, Juan A. García-Borbón ${ }^{2}$, Sergio Amezcua- \\ Castro $^{3}$, Sergio A. Pérez-Valencia ${ }^{4,5}$, Estefani Larios-Castro ${ }^{1}$ \\ ${ }^{1}$ Centro de Investigaciones Biológicas del Noroeste, La Paz, B.C.S., México \\ 2 Instituto Nacional de Pesca (CRIAP), La Paz, B.C.S., Mexico \\ 3 Centro Interdisciplinario de Ciencias Marinas, La Paz, B.C.S., México \\ 4 Centro Intercultural de Estudios de Desiertos y Océanos A.C., Puerto Peñasco, Sonora, México \\ 5 Comisión Nacional de Áreas Naturales Protegidas, Hermosillo, Sonora, México \\ Corresponding Author: Enrique Morales-Bojórquez \\ Email address: embojorq@prodigy.net.mx
}

Stock assessment of the geoduck clam Panopea globosa in Mexico has been based on data-poor without consideration of the biological traits of the species, promoting a passive management strategy without biological reference points for its harvest and conservation, which results in limited advice regarding the sustainability of the fishery. The stock assessment was supported on an integrated catch-at-size assessment model. The model described the population changes, including recruitment, selectivity, fishing mortality, individual growth patterns and survival over time, providing management quantities for the geoduck clam fishery, such as biomass-at-length (total and vulnerable) and harvest rate-at-length. The results indicated overfishing of the geoduck clam population; the harvest rate exceeded the management tactics established for this fishery, even the individuals smaller than the minimum legal size $(130 \mathrm{~mm})$ were harvested. Thus, declines in the total biomass (from 3,262 to 1,130 t) and recruitment (representing an $86 \%$ decrease) were observed from 2010 to 2012. Although the results showed a recovery trend in recruitment and total biomass from 2014 to 2016, this trend may have been due to the spatial relocation of fishing mortality. 
1 Evidence of overfishing of geoduck clam Panopea globosa from a length-based stock

2 assessment approach

3

4

5 Marlene Anaid Luquin-Covarrubias ${ }^{1}$, Enrique Morales-Bojórquez ${ }^{1 *}$, Juan Antonio García-

6 Borbón $^{2}$, Sergio Amezcua-Castro ${ }^{3}$, Sergio Alejandro Pérez-Valencia ${ }^{4,5}$, Estefani Larios-Castro ${ }^{1}$

$9 \quad{ }^{1}$ Centro de Investigaciones Biológicas del Noroeste. La Paz, B.C.S., México.

10 mluquin@pg.cibnor.mx, emorales@cibnor.mx, elarios@pg.cibnor.mx

11

12 Instituto Nacional de Pesca (CRIAP). La Paz. La Paz, B.C.S., México.

13 antonio.borbon@inapesca.gob.mx

${ }^{3}$ Centro Interdisciplinario de Ciencias Marinas. La Paz, B.C.S., México. samezcuac@gmail.com

${ }^{4}$ Centro Intercultural de Estudios de Desiertos y Océanos A.C. Puerto Peñasco, Sonora, México.

18 sergio.perez@conanp.gob.mx

${ }^{5}$ Current address: Comisión Nacional de Áreas Naturales Protegidas. Hermosillo, Sonora.

21 México.sergio.perez@conanp.gob.mx

22

23

$24 *$ Corresponding author:

25 Enrique Morales Bojórquez

26 Email: emorales@cibnor.mx

27 Phone: +526121238484 ext. 3351 


\section{Abstract}

29

30 Stock assessment of the geoduck clam Panopea globosa in Mexico has been based on data-poor

31 without consideration of the biological traits of the species, promoting a passive management

32 strategy without biological reference points for its harvest and conservation, which results in

33 limited advice regarding the sustainability of the fishery. The stock assessment was supported on

34 an integrated catch-at-size assessment model. The model described the population changes,

35 including recruitment, selectivity, fishing mortality, individual growth patterns and survival over

36 time, providing management quantities for the geoduck clam fishery, such as biomass-at-length

37 (total and vulnerable) and harvest rate-at-length. The results indicated overfishing of the geoduck

38 clam population; the harvest rate exceeded the management tactics established for this fishery,

39 even the individuals smaller than the minimum legal size $(130 \mathrm{~mm})$ were harvested. Thus,

40 declines in the total biomass (from 3,262 to 1,130 t) and recruitment (representing an 86\%

41 decrease) were observed from 2010 to 2012. Although the results showed a recovery trend in

42 recruitment and total biomass from 2014 to 2016, this trend may have been due to the spatial

43 relocation of fishing mortality.

45 Keywords: Population dynamics, length structure, management strategy, biomass, overfishing. 


\section{Introduction}

Stock assessment and fishing management are crucial when starting a new fishery because there is high uncertainty whether the catch levels will be sustainable; thus, increases in the fleet size and fishing effort could lead to depletion of the stock, which occurs when commercial catches decrease under an optimal economic yield (Branch et al., 2006). Moreover, delayed implementation of management reforms has negative effects on stock conditions and fishery benefits; it significantly reduces biomass levels, harvest and profits; in addition, delayed influences on continuous declines, increase the risk of collapse and delay the recovery of stocks (Mangin et al., 2018). Collapses have been documented for several stocks of sedentary organisms, such as abalone (Haliotis spp.), which are distributed from southeast Alaska to southeast California, where regional management strategies have failed to consider the biology and distribution of the populations (Hilborn, Orensanz \& Parma, 2005). The zigzag scallop (Euvola ziczac) in Brazil was not considered a target species; therefore, management strategies were not developed, and the stock irreversibly collapsed (Pezzuto \& Borzone, 2004). Finally, the smooth clam (Callista chione) in the northwestern Mediterranean Sea declined due to the association between the increase in fishing effort and sand dredging (Baeta, Ramón \& Galimany, 2014). Similar events occurred for P. generosa in Canada and P. zelandica in New Zealand, where the total allowable catch was exceeded; thus, moratorium and fishery closures were implemented to stabilize the populations (Khan, 2006; Gribben \& Heasman, 2015). For long-lived organisms such as the species of the genus Panopea, recovery of the stock can be extremely slow. The main disadvantage is that these species have complex population dynamics characterized by prolonged longevity, low recruitment, variable individual growth rates, and high natural mortality rates in young individuals (Goodwin \& Pease, 1991). Additionally, geoduck populations are composed of many annual classes, suggesting an apparent stable abundance, which makes them particularly vulnerable to depletion (Orensanz et al., 2004).

In Mexico, the geoduck clam constitutes a small-scale fishery that has been developed for two species: Panopea generosa in the northwest Mexican Pacific and Panopea globosa in the Gulf of California and southwest of the Baja California Peninsula. For both species, harvesting increased quickly, reaching landings from 38 to 2,000 t during 2002-2011 (Aragón-Noriega et al., 2012). 
77 However, one of the main problems for managing this fishery is the lack of key and continuous

78

79

80

81

82

83

84

85

86

87

88

89

90

91

92

93

94

95

96

97

98

99

100

101

102

103

104

105

106

107 information that is needed to apply models and reliable stock assessments (Arreguín-Sánchez \& Arcos-Huitrón, 2011; Ramírez-Rodríguez \& Ojeda-Ruiz, 2012). According to Dowling et al. (2015), the geoduck clam fishery could be classified into two categories. 1) A data-poor fishery: it has limitations in terms of the type and quality of available data; therefore, quantitative stock assessments are impossible to perform; given that the best available information is inadequate, reference points and the exploitation status of the stock cannot be determined. 2) A data-limited fishery: additional information sources on catch and effort data can be included, but the amount of information is not sufficient to perform a quantitative stock assessment. In addition, in species with complex or unknown life histories, the stock status is unable to be determined.

For Panopea spp. in Mexico, the stock assessment has been based on fishery-independent surveys, estimating densities and biomasses through extrapolation for known areas, which have important implications for fishery management because this assessment defines the stock size susceptible to fishing (Zhang \& Hand, 2006; Cortez-Lucero et al., 2014). This stock assessment method was adopted from management schemes applied to geoducks in Washington State, USA, and British Columbia, Canada, in the 1970s (Goodwin \& Pease, 1991; Zhang \& Hand, 2006), to establish an initial strategy for regulating the geoduck fishery in Mexico. Thus, during the discovery and growth phases of the geoduck clam fishery, the main dynamic was the entry of new participants, the expansion of fishing capacity, and the exploration of new patches and beds. These activities were regulated through management tactics, such as 1) a minimum legal size of $130 \mathrm{~mm}$ shell length; 2) a maximum allowable catch of $0.5 \%$ of the estimated total biomass (predevelopment phase) or 1\% from a growth phase of the geoduck clam fishery; and 3) requiring the density of the bed to be exploited to be greater than 0.4 geoducks $/ \mathrm{m}^{2}$ (AragónNoriega et al., 2012). However, these guidelines did not consider the biological traits and population dynamics of geoduck and were limited to determining changes in stock size (e.g., biomass, recruitment), restricting estimates of harvest rate and fishing mortality and failing to provide biological reference points for indicating levels of caution in the fishery; this approach is characterized as passive management scheme (Cadrin \& Pastoors, 2008; Fitzgerald, Wilson \& Lenihan, 2018). Eventually, during the development of a fishery, the management strategies must change and adapt to the obtained biological knowledge to improve the assumptions about 
108 the status of the stock (Hilborn \& Walters, 1992). However, stock assessment and fishing 109 management for the geoduck clam fishery have not been updated over the last 16 years of

110 harvest, and the basic assumptions about the stock remain unchanged. Thus, the aim of this study

111 is to analyze the effects of fishing pressure on the population of the geoduck clam Panopea

112 globosa in Puerto Peñasco, Sonora, Mexico.

113

\section{Materials and methods}

116 Shell length structure and catch data

117 Biological data were obtained from Puerto Peñasco, Sonora, in the upper Gulf of California, 118 Mexico (Fig. 1), during two time periods: 2010 to 2012 and 2014 to 2016 . A total of 19,445

119 individuals of $P$. globosa were collected from two sources of information. The first source was a

120 sampling design based on the estimation of the fishing ground. To this goal, a survey was

121 conducted to identify the patches and beds with high abundance; the fishing ground was

122 estimated based on the boundaries of sampling stations, and the area was expressed as $\mathrm{km}^{2}$.

123 Sampling stations were performed randomly every $1 \mathrm{~km}$ along the fishing ground using a

124 sampling unit of $50 \mathrm{~m}^{2}(25 \mathrm{~m} \times 2 \mathrm{~m}$ transect $)$. The second source of biological data was obtained

125 from commercial landings, which were endorsed by fishing licenses that establish basic

126 conditions for the extraction activities. During the predevelopment phase of geoduck fishery, a

127 legal requirement for the fishers was annual data collection and analysis of the harvest

128 population; however, when the analysis of the fishing ground indicates the availability of

129 sufficient biomass for exploitation, then the fishing ground is classified as being in growth phase;

130 thus, the data collection for the authorized beds must be analyzed every three years.

131 Consequently, the data collection is not mandatory for the fishers, and the biological information

132 may be limited due to the cost of the geoduck monitoring program, which was not implemented

133 during 2013. According to the bathymetry around Puerto Peñasco (Ramírez-Mendoza \& Álvarez,

134 2009), the commercial harvest was performed between 10 and $30 \mathrm{~m}$ deep; greater depths are

135 restricted by the Mexican government to avoid the decompression sickness of divers. Geoduck

136 harvest was performed by hookah diving during low tides, with small boats equipped with an

137 outboard motor and a low-pressure compressor connected to a hose. Geoducks were located

138 through their siphon holes on the substrate, and they were removed using a water jet to loosen 
139 the sediment. Shell length $(\mathrm{mm})$ and total weight $(\mathrm{g})$ data were recorded monthly; the specimens

140 were grouped by shell length frequency distributions by year, and the size classes varied from 78

141 to $200 \mathrm{~mm}$ shell length.

142

\section{Data origin}

144 The annual catch data were obtained from the Subdelegación Federal de Pesca at Puerto

145 Peñasco, Sonora, Mexico (Comisión Nacional de Acuacultura y Pesca, CONAPESCA)

146 (https://www.conapesca.gob.mx/wb/cona/estadisticas de produccion pesquera).

147 Scientific collecting and the use of biological and fishery data was endorsed by the Mexican

148 federal government (CONAPESCA) through the commercial fishery permit numbers

149 DGOPA.05338.050710.3326 (2010), DGOPA.09450.221111.3442 (2011), 126054025018

150 (2012), PPF/DGOPA-186/14 (2014), 126070025019 (2015), and 126047025017 (2016) with

151 fishermen of the SCPP Buzos de Puerto Peñasco, SCPAP Islas de Sonora, SCPP Jaiberos y

152 Escameros, and SCPP Mar y Tierra del Golfo de Cortez.

153

\section{Population dynamics}

155 The population dynamics of $P$. globosa was analyzed using an integrated catch-at-size

156 assessment (ICSA) model (Morales-Bojórquez, López-Martínez \& Beléndez-Moreno, 2013). To

157 provide a better description of the model, a summary of the symbols and descriptions of the

158 parameters and variables are defined in Table 1. The ICSA model describes the population

159 changes over time for multiple shell length classes according to the following: a) the total

160 mortality of geoducks in shell length class $l$ at time $t$, representing the sum of fishing and natural

161 mortality $\left(Z_{l, t}=F_{l, t}+M_{l, t}\right)$, and b) the relationship between $N_{l, t}$ and $N_{l, t}$, which denotes the

162 number of geoducks at shell length surviving and growing during the next time period according

163 to the equation $N_{l, t^{\prime}}=N_{l, t} e^{-Z_{l, t}}$. A natural mortality value of 0.046 was used for modeling the

164 population dynamics of geoduck clam (González-Peláez et al., 2015a); this fixed parameter was

165 based on the number of gnomonic intervals determined by dividing the life history of the

166 geoduck into a predetermined number of biological units (life stages). The advantage of this

167 method is that uses the biological information of the lifespan for knowledge of the ontogenic

168 changes in natural mortality; this procedure is better than estimations based on meta-analysis 
169 because these approaches were developed for specific taxa, such as fishes (Pauly, 1980),

170 empirical approaches based on biological parameters (Hoening, 1983) or based on life strategy

171 (r-K selection) (Gunderson, 1980). A gnomonic interval is a systematic strategy for the unequal

172 subdivision of the lifespan of an individual into time intervals, which increase in duration and

173 proportion for each time interval. Therefore, in terms of elapsed time, two gnomonic intervals in

174 a subdivided life history can be considered equivalent if they each form the same constant

175 proportion of the time elapsed (Caddy, 1996; Ramírez-Rodríguez \& Arreguín-Sánchez, 2003;

176 Martínez-Aguilar, Arreguín-Sánchez \& Morales-Bojórquez, 2005; Aranceta-Garza et al., 2016;

177 Romero-Gallardo et al., 2018). Thus, the natural mortality of P. globosa was modeled as

178 follows: 1) egg to trochophore larvae (24 hours); 2) early larvae (6.5 days); 3 ) late larvae (11

179 days); 4) early juveniles (35 days); 5) juveniles (3-9 months); 6) late juveniles (1-2 years); and

180 7) preadult to adults (3-47 years). Basically, the fishery maintains high fishing pressure on

181 biological unit 7; such that $M=0.046$ is a plausible value; additionally, the comparison between

182 the gnomonic method and alternative procedures yielded similar values for geoducks larger than

$183130 \mathrm{~mm}$; therefore, the natural mortality was relatively stable for individuals from preadult to

184 adult (Calderon-Aguilera et al., 2010b; González-Peláez et al., 2015a). The catch $\bar{C}_{l, t}$ was

185 calculated using the Baranov catch equation, $\bar{C}_{l, t}=N_{l, t} \mu_{l, t}$, where $\mu_{l, t}$ is the harvest rate defined

186 as the proportion of individuals that die from fishing mortality compared to total mortality $\mu_{l, t}=$

$187 F_{l, t} / Z_{l, t}\left(1-e^{-Z_{l, t}}\right)$.

188

189

Initial conditions

190 The number of individuals of the geoduck clam population at the beginning of the time period

191 denotes the initial stock abundance, which was estimated as $N_{0}=\sum_{l} N_{l, 0}$, where $N_{l, 0}$ was

192 estimated as $N_{l, 0}=\frac{C_{l, 0}\left(Z_{l, 0}\right)}{F_{l, 0}\left(1-e^{-Z_{l, 0}}\right)}$. In this way, the proportion of geoducks in shell length class $l$

193 was calculated as $P_{l}=\frac{C_{l, 0} Z_{l, 0} / F_{l, 0}\left(1-e^{-Z_{l, 0}}\right)}{\sum C_{l, 0} Z_{l, 0} / F_{l, 0}\left(1-e^{-Z_{l, 0}}\right)}$. Thus, the shell length distribution of abundance was

194 computed as $\hat{N}_{l, 0}=\hat{P}_{l} N_{0}$. This procedure simplifies the parameter space for estimating only one

$195 N_{0}$ instead of estimating a vector of $N_{l, 0}$, increasing the performance of the objective function.

196

Peer] reviewing PDF | (2019:10:42044:1:2:NEW 31 Mar 2020) 


\section{Recruitment}

198 Usually, estimates of recruitment are based on a stock-recruits relationship, as in the studies by Beverton-Holt (1957) and Ricker (1954, 1975). However, establishing a functional stock-recruits relationship for the geoduck clam is very difficult; therefore, recruitment in the Panopea genus is only measured in terms of recruitment rates (Zhang \& Hand, 2006). Sullivan, Lai \& Gallucci (1990), Fisch et al. (2019) and Amezcua-Castro et al. (2019) used length-structured models and proposed that recruitment can be estimated from a gamma probabilistic density function, assuming that it can represent the variability in recruitment. Biologically, recruitment represents the number of individuals at specific age or length classes that are added to the exploitable stock in the fishery (Myers, 2002). Recruitment is modeled as the product of a time-dependent variable $\left(R_{t}\right)$ corresponding to the annual recruitment and a length-dependent variable $\left(\varphi_{l}\right)$, representing the proportion of the annual recruitment into each length class $l$. This proportion $\varphi_{l}$ of recruits in each length class was estimated following a gamma distribution with recruitment parameters $\alpha_{r}$ and $\beta_{r}$. Thus, the equation for estimating recruitment-at-shell length was $R_{l}=R_{t} \varphi_{l}$ (Fisch et al.,

211 2019); this procedure of separating variables allows $R_{t}$ to be compared with recruitment

212 estimates from standard procedures. According to Sullivan, Lai \& Gallucci (1990), recruitment

213 specified in this way represents the type of recruitment observed in nature, where variation in

214 growth, behavior, or food supply can result in individuals entering the population at several

215 length classes. Given that the recruitment to the fishery occurs over a range of shell length

216 classes, we grouped the number of individuals with shell length between 78 and $130 \mathrm{~mm}$ (which

217 were caught from the fishery) to represent the recruits added to fishable stock.

218

\section{Fishing mortality and selectivity}

220 The assumption in the ICSA model is that the fishing mortality vector can be partitioned into two components: i) a shell length-specific component that does not vary over time (e.g., a constant exploitation pattern) and ii) an annual multiplier commonly specified as catchability, vulnerability or selectivity (Megrey, 1989). Thus, in this study, the fishing mortality was estimated as a separable product of the shell length selectivity and the full-recruitment fishing mortality rate: $F_{l}=s_{l} f_{t}$. The separability assumption allows the estimation of only a fishing mortality value, which is distributed proportionally in the shell length classes, improving the performance of the model parameterization (Fisch et al., 2019). To analyze $s_{l}$, a gamma 
228 probabilistic function was applied; the advantage of this approach is that it provides great

229 flexibility to the model, allowing different selectivity patterns (Carlson \& Cortés, 2003). Thus,

$230 s_{l}$ was estimated as $s_{l}=\left(l / \alpha_{s} \beta_{s}\right)^{\alpha} s \exp \left(\alpha_{s}-l / \beta_{s}\right)$. The parameterization was based on the

231 residual sum of squares $\left(R S S_{S}\right)$ function:

232

$$
R S S_{s}=\sum_{i=1}^{n}\left(s_{l}-s_{o, l}\right)^{2}
$$

233

234

235

236

237

238

239

240

241

242

244

$$
G_{l, l+1}=\int_{l+1_{1}}^{l+1_{2}} \mathrm{~g}\left(\mathrm{x} \mid \alpha_{l}, \beta_{\mathrm{g}}\right) \mathrm{dx}
$$

245

246 The survival matrix was estimated as $e^{-Z}$ l,t , and the transition matrix was calculated as follows: 247

$$
T_{l, t}=\sum_{l} G_{l, l+1} S_{l, t}
$$




\section{Parameter estimation}

250 The ICSA model was fitted through the residual sum of squares (RSS) criterion:

251

$$
R S S=\sum_{l, t}\left(\bar{C}_{l, t}-C_{l, t}\right)^{2}
$$

252 The parameters were estimated by minimizing the objective function (RSS) with a nonlinear fit

253

254

255

256

257

258

259

260

261

262

263

264

265

266

267

268

269

270

271

272

273

274

275

277

276 using $T_{l, t}$ and $\hat{N}_{l, 0}$. The recruitment-at-shell length was added to represent the population using the Generalized Reduced Gradient (GRG) algorithm (Neter et al., 1996). The optimization was performed in phases; this procedure consists of estimating only a subset of parameters through the optimization of the objective function and adding more parameters in each sequential phase until all parameters are estimated. An advantage is that to the extent that new parameters are included into a new phase, the previously estimated parameters are still estimated, and they are not fixed as prespecified values, allowing the progressive improvement of the goodness of fit of the RSS (Legault \& Restrepo, 1998; Luquin-Covarrubias et al., 2016). A non-linear fit in phases is an statistical procedure accepted when there is high uncertainty in seed values and where the number de parameters to be estimated is greater than 20 (Fournier et al., 2012; Punt, Huang \& Maunder, 2013; Canales, Company \& Arana, 2016; Cao, Chen \& Richards, 2016; Fisch et al., 2019). According to Fournier et al. (2012), this procedure is also called "model sculpting". Thus, the $F_{l, t}$ vector was known when $f_{t}$ was included in the numerical optimization process in the first group of parameters; the second group of parameters included $N_{l, 0}$, the third group integrated $R_{t}, \alpha_{r}$ and $\beta_{r}$, and the fourth group incorporated $\beta_{g}$. The $\alpha_{s}$ and $\beta_{s}$ parameters were independently estimated and later integrated into the $R S S$ as a fifth group. For ICSA model if any parameters are known, then they can be prespecified instead of estimated (Sullivan, Lai \& Gallucci, 1990); thus, the parameter $L_{\infty}=200 \mathrm{~mm}$ was assigned according to the largest observed shell length, $k=0.25$ was assigned from the von Bertalanffy growth model, reported by Aragón-Noriega, Calderon-Aguilera \& Pérez-Valencia (2015), and $M=0.046$ was assigned based on the report by González-Peláez et al. (2015a).

\section{Management quantities}

75 In this study, the total abundance-at-shell length of the geoduck clam population was estimated dynamics of the geoduck clam as follows: 
278

$$
N_{l^{\prime}, t^{\prime}}=\sum_{l} T_{l, t} \hat{N}_{l, 0}+R_{l, t}
$$

279

280 The total and vulnerable biomass-at-shell length were estimated as follows:

281

$$
T B_{l}=\sum_{i=1}^{n} N_{l, t}, \omega_{l}
$$

282

$$
V B_{l}=\sum_{i=1}^{n} N_{l, t}^{\prime,} \omega_{l} S_{l}
$$

283

284 where $\omega_{l}$ was estimated from the power equation $\omega_{l}=\alpha l^{\beta}$ (González-Peláez et al., 2015b). 285

286

\section{Results}

287

288

289

\section{Shell length structure}

The time series showed that from 2010 to 2012, the shell length frequency distributions were similar; the most harvested shell length classes were between 126 and $174 \mathrm{~mm}$, while the least harvested shell length classes were between 178 and 198 mm. From 2014 to 2016, a marked change was observed in the total shell length frequency distribution. We noted an increase in harvest of individuals with a shell length less than $110 \mathrm{~mm}$. Although the shell length classes mostly harvested (118 and $178 \mathrm{~mm})$ and less predominant (182 and $198 \mathrm{~mm}$ ) were similar to those caught during the first three years, we observed that shell length frequency of geoduck clam was fragmented from 2014-2016, and the bell shape of the shell length frequency observed

297 during 2010-2012 changed to an irregular shape during 2014-2016. During the first three years

298 (2010-2012), the total number of individuals caught per shell length class decreased. In contrast, 299 during the second period from 2014-2016, the catches increased along the shell length frequency 300 distribution; thus, two periods were clearly distinguishable (Fig. 2).

\section{Recruitment}


303 The recruitment estimated for $P$. globosa showed a negative trend from 2010 to 2012, with

304 values of $2.78 \times 10^{6}, 1.93 \times 10^{6}$ and $3.75 \times 10^{5}$, respectively. This sudden decrease to the lowest

305 level represented a change by one order of magnitude in 2012 and a loss of $86 \%$ of the

306 recruitment abundance, indicating a decrease over a very short period of time. Subsequently,

307 recruitment increased from $8.85 \times 10^{5}(2014)$ to $1.76 \times 10^{6}(2015)$ and $3.02 \times 10^{6}(2016)$,

308 reaching recruitment levels slightly greater than those estimated in 2010. Figure 3 shows the

309 changes in number of recruits to the fishery (from 78 to $130 \mathrm{~mm}$ ) estimated in our study.

310

311 Fishing mortality and selectivity

312 The fishing mortality estimates calculated by the ICSA model varied over time. The geoducks of

$313166 \mathrm{~mm}$ shell length experienced the main fishing pressure along the time series, exhibiting the

314 highest fishing mortality during 2016 (0.79), followed by 2011 (0.63), 2010 (0.62) and 2012

315 (0.42). In 2014, fishing mortality showed two peaks at 0.36 in the 158 and $166 \mathrm{~mm}$ shell length

316 classes. Finally, during 2015, a peak of 0.22 was observed for the $158 \mathrm{~mm}$ shell length class.

317 Comparatively, the lowest fishing mortality $(<0.05)$ occurred in individuals in the shell length

318 classes of 78-130 mm (2010-2016) and those larger than $190 \mathrm{~mm}$ (2011-2015). Fishing mortality

319 increased in the $194 \mathrm{~mm}$ shell length class only during 2010 and 2016 (Fig. 4a,b).

320

321 The selectivity showed a decrease in shell length from 150 (2012) to $142 \mathrm{~mm}$ (2016). This

322 change was observed in the shell length selectivity of geoducks that had a $50 \%$ probability of

323 being caught by a diver; this value was defined as $S_{l 50 \%}$ (Fig. 5). The selectivity estimates for the

324 analyzed years showed the lowest values $(<0.07)$ for the shell length classes between 78 and 118

$325 \mathrm{~mm}$. Changes in selectivity from 2010 to 2015 showed an accelerated increase from 0.2 to 0.99

326 for individuals with shell lengths between 122 and $174 \mathrm{~mm}$. Comparatively, during 2016, the

327 changes in selectivity included smaller individuals and a wider shell length range (110-174 mm),

328 with values between 0.03 and 0.99 . Finally, the geoducks in the shell length classes larger than

$329178 \mathrm{~mm}$ attained the maximum selectivity.

330

331 Management quantities

332

333 Harvest rate 
334 The tendency of the harvest rates of geoducks between 78 and $115 \mathrm{~mm}$ varied slightly

335 throughout the time series, exhibiting values less than 0.05 ; subsequently, the harvest rate

336 estimates gradually increased for geoducks from 118 to $130 \mathrm{~mm}$, reaching a maximum value of

3370.16 (2014) for geoducks of $130 \mathrm{~mm}$ (Fig. 6a,b). For individuals larger than the minimum legal

338 size, an increasing trend in the harvest rate-at-shell length was also observed. Thus, the

339 individuals between 154 and $178 \mathrm{~mm}$ reached maximal values of 0.48 (2010), 0.49 (2011), 0.36

340 (2012), 0.37 (2014), 0.26 (2015) and 0.56 (2016). A decreasing harvest rate-at-shell length

341 occurred from 2011 to 2015 for the shell length classes between 182 and $198 \mathrm{~mm}$; however, for

3422010 and 2016, a patch of large geoducks was located and harvested; consequently, the harvest

343 rate of the $194 \mathrm{~mm}$ shell length class suddenly increased. Although the fishing pressure on

344 geoducks, expressed as the harvest rate-at-shell length, was highly variable among the years

345 analyzed, we observed a general pattern over time: the shell length classes between 142 and 174

$346 \mathrm{~mm}$ accounted for more than $50 \%$ of the harvest (Fig. $7 \mathrm{a}, \mathrm{b}$ ).

347

\section{Total and vulnerable biomass}

349 The estimates of total biomass-at-shell length showed changes along the time series; from 2010

350 to 2012, the total biomass-at-shell length decreased; subsequently, an increase was observed

351 during 2014 and 2015, with a slight decrease in 2016 (Table 2). In the first period, the maximum

352 estimates of total biomass were $204.54 \mathrm{t}$ (2010) and $161.10 \mathrm{t}$ (2011) for the shell length class of

$353122 \mathrm{~mm}$; then, the total biomass-at-shell length rapidly decreased to $65.41 \mathrm{t}$ (2012) for geoducks

354 in the shell length class of $146 \mathrm{~mm}$. During the second period (2014-2016), the highest values of

355 total biomass-at-shell length were $266.66 \mathrm{t}$ (2014), $265.75 \mathrm{t}$ (2015) and $224.36 \mathrm{t}$ (2016) for the

356 shell length classes of $158 \mathrm{~mm}, 146$ and $126 \mathrm{~mm}$, respectively (Fig. 8a,b). The shell length

357 ranges most representative of geoduck clams associated with the total biomass were different for

358 each time period analyzed. For the first period, the range of shell length changed from 110-138

$359 \mathrm{~mm}(2010-2011)$ to $130-170 \mathrm{~mm}$ (2012). This change indicated that the total biomass of younger

360 individuals decreased, and during the third year, although the individuals were larger, their total

361 biomass was diminished, representing the year with the lowest biomass. During the second

362 period, the range of shell length progressively diminished, and the ranges among years were 138-

$363170 \mathrm{~mm}$ (2014), 130-138 mm (2015), and 110-142 mm (2016) (Fig. 8a,b). 
365 The time series showed that the vulnerable biomass-at-shell length decreased from 2010 to 2012 ;

366 subsequently, during 2014 and 2015, the vulnerable biomass exhibited an increase, diminishing

367 in 2016 (Table 2). During the first period, the peaks of vulnerable biomass were $72.93 \mathrm{t}$ (2010)

368 and $52.77 \mathrm{t}$ (2011) for the $154 \mathrm{~mm}$ shell length class and $43.62 \mathrm{t}$ during 2012 for individuals with

369 a shell length of $162 \mathrm{~mm}$. Comparatively, during the second period, the highest values of

370 vulnerable biomass were $237.90 \mathrm{t}$ (2014), $170.66 \mathrm{t}$ (2015), and $99.72 \mathrm{t}$ (2016) for the 178, 162

371 and $150 \mathrm{~mm}$ shell length classes, respectively. In the time series, vulnerable biomasses less than

$37225 \mathrm{t}$ were observed for individuals between 78 and $110 \mathrm{~mm}$ and larger than $186 \mathrm{~mm}$, excluding

373 2014, when the vulnerable biomass for individuals between 190 and $198 \mathrm{~mm}$ was not estimated

374 because these shell length classes were not harvested. Conversely, during 2015, the vulnerable

375 biomass for the individuals in the $198 \mathrm{~mm}$ shell length class showed a slight increase (Fig. 9a,b).

376

\section{Parameter estimation}

378 The parameters associated with the population dynamics of the geoduck clam were optimized for 379 each year of fishing analyzed, and the interaction between the different modules of the ICSA 380 model exhibited convergence in the objective function. Thus, the ICSA model showed high

381 performance in fitting the observed catch-at-shell length data, exhibiting low residual values $382($ RSS) (Table 3).

383

\section{Discussion}

385 The population dynamics of Panopea spp. are very different from those of r-selected species; 386 geoduck clam exhibits a longevity of 34 years in the study area (Aragón-Noriega, Calderon387 Aguilera \& Pérez-Valencia, 2015), late maturity, a low individual growth rate, and a high natural 388 mortality rate for early stages and young individuals (González-Peláez et al., 2015a). These 389 demographic traits make to geoduck susceptible to fishing mortality, negatively affecting its 390 abundance, spatial density, survival and reproduction rates; hence, stock management must avoid 391 significant decreases in abundance. Therefore, the correct interpretation of our results has a 392 biological component and a component associated with geoduck clam fishery management, 393 where the variability in recruitment and biomass are important to the population dynamics of the 394 geoduck clam. 
396 The results showed that individuals smaller than the minimum legal size $(130 \mathrm{~mm})$ were

397 harvested, even the harvest rate-at-shell length increased after 2010 and these clams are not

398 targets of the geoduck clam fishery. Moreover, individuals with shell lengths larger than $130 \mathrm{~mm}$

399 were also excessively harvested, with a harvest rate-at-shell length greater than $1 \%$, denoting that

400 the shell length structure of geoduck clam was overfished over time. Although a minimum legal

401 size of $130 \mathrm{~mm}$ was established as a management tactic to avoid growth overfishing, it failed to

402 maintain the sustainability of the geoduck clam stock in Puerto Peñasco, Sonora. Thus, two

403 overfishing patterns were simultaneously identified: a) growth overfishing (which occurs when

404 young clams are caught before reaching their optimal size and the fishery cannot produce the

405 maximum yield) and b) recruitment overfishing (which represents excessive fishing pressure on

406 the spawning stock, reducing its abundance to a very low level, at which the spawning stock

407 cannot produce enough new individuals for recruitment).

408

409 According to Hilborn \& Walters (1992), a rapid depletion and potential collapse occur in

410 commercial fisheries when failures in recruitment are observed. In this study, recruitment to the

411 fishery was assumed to occur over a range of shell length classes (78-130 mm); thus, a rapid

412 decrease in recruitment was observed, representing an $86 \%$ in the overall recruitment estimated

413 from 2010 to 2012. The sudden decrease in recruitment occurred after two years of excessive

414 harvesting of all sizes of $P$. globosa. Usually, the variability in recruitment of Panopea spp. can

415 be explained by the following: a) the failures in recruitment, which have been documented even

416 in years where there was not exploitation, thus the decrease is not attributable to harvest (Zhang

$417 \&$ Campbell, 2004); b) a loss of recruits, which has been identified in populations with low

418 densities of individuals (Campbell et al., 2004); c) synchronic variability in recruitment, which

419 has been corroborated by the comparison of fishing and nonfishing areas (Campbell et al., 2004);

420 d) negative effects of fishing mortality on recruitment, identifiable on a short-term scale

421 (Campbell et al., 2004); and e) declining and rebounding trends in recruitment, which have been

422 identified as consequences of environmental variables (Valero et al., 2004).

423

424 Additionally, for Panopea spp., failures in recruitment have been identified to occur when a

425 unimodal distribution pattern in the shell length structure is observed; this pattern is mainly

426 caused by the presence of old individuals and an evident lack of young individuals, indicating 
427 poor recruitment pulses (González-Peláez et al., 2015b). A low frequency of young individuals 428 can also be influenced by the spatial heterogeneity typical of Panopea spp. (patchy distribution), 429 where the recruits of a cohort can be located (settled and recruited) in different beds due to the 430 process of advection or the retention of larvae. As was reported for P. globosa in the upper Gulf 431 of California, the geoduck clam beds from Puerto Peñasco and Guaymas (east coast of the Gulf 432 of California) are influenced by the supplies of geoduck clam larvae from the San Felipe beds 433 (west coast of the Gulf of California) due to anticyclonic circulation during the spawning period 434 in the winter (Munguia-Vega et al., 2015). In addition, for geoduck clam fishery, the removal of 435 adults may reduce the reproductive output of the population.

436

437 Although this study is focused on the population dynamics of the geoduck clam and the 438 estimation of management quantities (e.g., biomasses), the changes in biomass and recruitment 439 could be explained by the management scheme currently applied to this fishery; the rationale is 440 based on the historical development of the geoduck clam fishery in the region. In Mexico, the 441 stock assessment of geoduck clam was initially based on data poor, and the management rules 442 originally proposed had the following limitations: 1) uncertainty in biomass estimates and a lack 443 of knowledge regarding biological reference points, 2) failure to identify warning signs of 444 depletion, and 3) poor management outcomes. Although specific fishing management plans by 445 species currently exist, these plans are not supported by biological and demographic bases of 446 Panopea globosa and P. generosa; therefore, the regulations are indiscriminate for both species 447 and they have been managed as a single species (Aragón-Noriega et al., 2012). The harvest rates 448 of $0.5 \%$ applied during the predevelopment phase (2008) and 1\% during the growth phase (2012) 449 of the geoduck clam fishery were adequately implemented during the first years as a result of the 450 management rules proposed by the Mexican government; however, the data and biological 451 knowledge were insufficient at that time. Consequently, the harvest policies were not evaluated 452 or updated in the short term, and passive management measures, such as regulations based on the 453 control of fishing effort, gear restrictions, and minimum harvest size, failed to maintain stable 454 geoduck biomass levels.

455

456 According to Zhang \& Hand (2006), a decay cohort model for geoduck can be used for modeling 457 the effect of a given exploitation rate; the assumption shows that if the population is close to the 
458 virgin condition, then a management strategy of constant harvest rate can be implemented into a 459 defined time scale. Zhang \& Hand (2006) performed a simulation projected forward for 50 years 460 by varying the exploitation rate from $0 \%$ to $4 \%$ using an increment of $0.5 \%$. Thus, the reference 461 point would be the $50 \%$ of the virgin biomass for a specific fishing ground; evidently if the 462 exploitation rate is increased and maintained constant over time, then the reference point is 463 reached in less time. This pattern indicates that although a harvest rate can be successfully 464 implemented, the time during which the fishing pressure can be applied is also important. For 465 geoducks in the study area, there are no estimates of population declines over time. The fishery began using a harvest rate of $0.5 \%$, which was later modified to $1 \%$. However, the use of this harvest rate did not allow the determination of whether the population was close to its virgin biomass; moreover, the addition of new beds and expansion of the fishing ground hide the effect of fishing on the geoduck population. Ideally, the harvest rate of $1 \%$ is adequate, but the implementation requires a time scale, which was fixed in 50-year horizon (Aragón-Noriega et al., 2012). However, this time horizon is based on geoduck clams distributed in northern latitudes (USA and Canada), where the longevity of this species has been estimated to exceed 100 years (Hoffmann, Bradbury, \& Goodwin, 2000; Bureau et al., 2002, 2003). In the study area, the species has exhibited longevity of 34 years (Pérez-Valencia \& Aragón-Noriega, 2013; Aragón-Noriega, Calderon-Aguilera \& Pérez-Valencia, 2015); therefore, the time horizon associated with the harvest rate should be shorter. According to Zhang \& Hand (2006), the ratio ( $\tau)$ of current biomass $\left(\mathrm{B}_{\mathrm{t}}\right)$ to virgin biomass $\left(\mathrm{B}_{0}\right)$ has the following relationships:

i) $\tau=\frac{B_{t}}{B_{0}}=0.5$; the value represents the biological reference point.

ii) $\tau=\frac{B_{t}}{B_{0}}<0.5$; recovery actions are necessary in the fishery.

480 iii) $\tau=\frac{B_{t}}{B_{0}}>0.5$; the harvest is allowed. Given that the lifespan of geoducks is limited to 34 years, a $\tau$ in which $\mathrm{B}_{0}$ includes a time 482 horizon of 50 years is not possible because the $\mathrm{B}_{0}$ under a constant harvest of $1 \%$ every year will cause total depletion of the virgin biomass sooner than 50 years. According to this rationale, the constant harvest of $1 \%$ for geoducks in the study area should be ideally applied over a 17 -year horizon. Therefore, an indicator of sustainability is not limited the allowable harvest rate; instead, the adequate indicator must be a specific $\tau$ value for each fishing ground, including a correct time horizon. 
488 Additionally, the regulation based on a minimum legal size assumes that all the individuals in the 489 shell length of $130 \mathrm{~mm}$ reached maturity and had at least one reproductive event $(D O F, 2012)$. 490 However, for populations of P. globosa from Guaymas and San Felipe in the Gulf of California, 491 a size-at-maturity at $50 \%$ of $88.75 \mathrm{~mm}$ and $89.37 \mathrm{~mm}$ shell length was determined, respectively; 492 these values were $41 \mathrm{~mm}$ below the minimum legal size established for the geoduck fishery 493 (Aragón-Noriega, 2015). Comparatively, the size-at-maturity at 50\% estimated for P. globosa 494 was higher than those reported for P. generosa in Washington (75 $\mathrm{mm}$ ) and two populations in 495 Canada: Gabriola Island $(58.3 \mathrm{~mm})$ and Yellow Bank $(60.5 \mathrm{~mm})$, as well as for two populations 496 of $P$. zelandica from New Zealand: Kennedy Bay $(55 \mathrm{~mm})$ and Shelly Bay $(57 \mathrm{~mm})$ (Andresen, 497 1971; Campell \& Ming, 2003; Gribben \& Crease, 2003). These differences in the maturity size 498 among populations of $P$. globosa should be taken into account when establishing management 499 strategies, mainly because the maturity size at 50\% is positively correlated with its longevity;

500 therefore, individuals mature at a specific fraction of their maximum length (Jensen, 1996; Law, 501 2000; Nadon \& Ault, 2006). For P. globosa, the individual growth is highly variable: in Bahía 502 Magdalena (Pacific coast), geoduck clams exhibited an asymptotic shell length of $179.85 \mathrm{~mm}$ 503 (Luquin-Covarrubias et al., 2016); the geoduck population from Guaymas (Central Gulf of 504 California) had an asymptotic length of $122 \mathrm{~mm}$ (Cortez-Lucero et al., 2011; Cruz-Vázquez et 505 al., 2012), while in Puerto Peñasco and San Felipe (Upper Gulf of California), the asymptotic 506 length values were $161.79 \mathrm{~mm}$ and $190.84 \mathrm{~mm}$, respectively (Aragón-Noriega et al., 2015). 507

508 Therefore, the minimum legal size of $130 \mathrm{~mm}$ is not a useful management rule because it is not 509 supported by the specific life history traits of Panopea globosa in each region. According to 510 Muse (1998), the minimum size limit is not a practical management tool for geoduck clams, and 511 the economic or management overvaluations can be a serious problem. The main reason is that 512 the mortality rate of discarded geoducks may be $100 \%$ because the shell length cannot be known 513 until the individual is extracted from the marine substrate. Additionally, geoducks are unable to 514 completely close their shells; thus, once an individual is removed, it cannot rebury itself, leaving 515 it vulnerable to depredation and dying within a short period of time. Given that the individuals to 516 be harvested are located through their siphon holes on the substrate, attempts to determine the 517 shell length through hole size or the width between paired siphon holes were documented for $P$. 518 generosa and P. zelandica, but these methods proved to be poor predictors of shell length 
519 (Andersen, 1971; Gribben \& Crease, 2005). Thus, Orenzans et al. (2004) explained that several

520 factors influence the vulnerability of geoduck clams, such as the experience of the divers and

521 their ability to identify beds with high densities or high numbers of siphons, which varies

522 according to type of substrate and affects harvest success. Initially, small clams were separated

523 from the harvest and fishers tried to rebury them in shoreline areas, but this practice did not

524 succeed because the geoducks did not remain buried in the marine substrate. Eventually,

525 geoducks from the $100 \mathrm{~mm}$ shell length had a high market price, and their harvest began to be a

526 profitable activity (Aragón-Noriega, 2015). Consequently, geoducks smaller than minimum legal

527 size were harvested in Puerto Peñasco; however, these individuals were not reported, affecting

528 the quantification of harvest rate legally established at $0.5 \%$ and $1 \%$. Potentially, the harvest

529 could be greater, causing a rapid depletion of the fishing ground as indicated by the dramatic

530 changes in harvest rate-at-shell length estimated in this study.

531

532 Geoduck clams, Panopea globosa, are spatially structured as "meta-populations," in which

533 benthic subpopulations are connected with each other through the dispersal of pelagic larvae.

534 Within populations, individuals are patchily distributed. According to Orensanz et al. (2016), a

535 fishing ground is typically occupied by a meta-population. Beds within a fishing ground are

536 more or less discrete areas with high density. Finally, within beds, individuals are distributed and

537 concentrated in patches of relatively high density. Thus, the results obtained from the ICSA

538 model represent the changes in the population dynamics at length from only one population of $P$.

539 globosa as well as from different fishing beds within the population. According to technical

540 reports published by the National Fishery and Aquaculture Institute from Mexico (governmental

541 agency for fishery management) (Ochoa-Araiza et al., 2014; 2015), we observed spatiotemporal

542 changes in the harvestable area; a) from 2009 to 2012 (fishery predevelopment phase), small

543 patches were initially identified and harvested, mainly into shoreline areas; and b) from 2013 to

5442016 (fishery growth phase), several patches were added, and the fishing area was expanded;

545 thus, the harvest of geoduck clams progressed offshore. Spatially, from 2009 to 2016, the fishing

546 area increased in size toward the southeast of the study area, indicating the greater expansion of

547 the harvestable area in the region. Comparatively, the fishing zone in the northeast area suffered

548 fragmentation, which means that the initially harvested patches showed spatial reductions such

549 that only a small area remained (Fig. 10, Appendix A1). The spatial changes had negative 
550 impacts for several benthic populations; for example, the Haliotis spp. stocks suffered a dramatic

551 serial depletion, both spatially and by species, and were gradually replaced by other abalone

552 species until their decline (Karpov et al., 2000; McCormick, 2000; Morales-Bojórquez et al.,

553 2008). Another example is the Catarina scallop (Argopecten circularis), which was exploited in

554 shallow beds; when the landings attained the maximum levels, the areas were overfished, and the

555 divers progressively moved their fishing grounds to deeper beds (Maeda-Martínez et al., 1993;

556 Rothschild et al., 1994; Tracey \& Lyle, 2011). In this study, changes in the total and vulnerable

557 biomass of geoduck clam occurred in a short period time, indicating a decrease from 2010 to

5582012 and an increase from 2014 to 2016, which cannot be explicitly explained by the population

559 dynamics of long-lived species such as P. globosa. Recently, these declines and recoveries of

560 recruitment and biomass (total and vulnerable) in a short time were also observed in the

561 population of $P$. globosa in Bahia Magdalena, where they were associated with an effect of serial

562 depletion (Amezcua-Castro et al., 2019).

563

564 According to the bathymetry around Puerto Peñasco, the geoduck fishing beds are located at

565 depths between 2 and $30 \mathrm{~m}$, but the commercial harvest has gradually moved from the shoreline

566 (9 m) to offshore areas $(30 \mathrm{~m})$. For geoduck clam, factors such as the depth, current flow,

567 substrate composition, and geographic area have been shown to affect the shell length of

568 individuals in any particular bed (Goodwin \& Pease, 1991). These authors also showed

569 significant differences in the shell length of geoducks at several depths, indicating a decrease in

570 shell length from $146.2 \mathrm{~mm}$ in shallow areas $(9.1 \mathrm{~m})$ to $125.8 \mathrm{~mm}$ in deeper waters $(13.7 \mathrm{~m})$. Our

571 results showed a change in the shell length frequency distribution during the second period

572 (2014-2016), representing a high harvest of individuals smaller than $110 \mathrm{~mm}$ as well as a

573 reduction of $8 \mathrm{~mm}$ in the $S_{l 50 \%}$, these changes coincided with the movement of fishing activity to

574 deep waters $(30 \mathrm{~m})$, where different conditions than those of shallow water can influence the

575 growth of geoducks. Geoducks live buried up to $1 \mathrm{~m}$ deep within sand and mud substrates, and

576 they feed by filtering phytoplankton from sea water (Goodwin \& Pease 1989); thus, in deep

577 areas where the current speed is typically lower, the deposition of fine sediment affects the food

578 availability and therefore reduces the growth of the geoducks to smaller lengths in comparison

579 with those living in high-current areas (Goodwin \& Pease, 1991). In this way, given the changes

580 in the fishing area and the relocation of fishing mortality, a spatial serial depletion could be 
581 operating in this fishery (Botsford, Campbell \& Miller, 2004; Orensanz et al., 1998; Kirby,

582 2004). Fishers are moving the fishing effort along the latitudinal gradient and from shoreline to

583 offshore areas; therefore, the biomass and recruitment cannot be adequately quantified because

584 new beds containing an abundance of younger $P$. globosa individuals may be available for

585 harvest. For this reason, the results obtained from the ICSA model showed an increasing trend in

586 the recruitment and biomass estimates; however, both increases may be masked due to serial

587 depletion.

588

589 Therefore, some type of area management is necessary for this sedentary species to maximize the

590 yield, as has been established for the Panopea generosa fishery in British Columbian waters,

591 where a "three-year rotation time" is maintained within three regions (north, central, and south)

592 and each region is divided into three subregions, with one out of three subregions within each

593 region harvested every 3 years. For Washington, USA, a preharvest survey is conducted in each

594 tract to estimate the biomass available for the geoduck fishery; if this biomass is high enough,

595 then the harvest is authorized. A depleted tract cannot be opened to the harvest until a survey

596 indicates that it has recovered to preharvest conditions. The geoduck management uses a de facto

597 rotation, where the fast-recovery tracts would be revisited more often than slow-recovery ones

598 (Orensanz et al., 2004). For Mexican waters, although area rotations are considered in the fishery

599 management plan, this practice is not adequately implemented. Rotational fishing is part of a

600 precautionary approach, and the Mexican geoduck clam fishery needs to analyze the possibility

601 of managing high- and low-productivity regions separately or to use an area rotation system to

602 prevent possible declines in the different populations. Explicitly, two options for area

603 management should be analyzed: a) pulse rotation (high levels of effort applied in an area when

604 it is opened, and all exploitable organisms are harvested at periodic intervals); and b) symmetric

605 rotation (which requires less concentrated effort and allows areas to be open half the time). The

606 advantage of rotational fishing is that it prevents the impact of both growth and recruitment

607 overfishing (Myers, Fuller \& Kehler, 2000; Hart, 2001; 2003; Harris, Adams \& Stokesbury,

608 2018).

609

610 Conclusions

611

Peer] reviewing PDF | (2019:10:42044:1:2:NEW 31 Mar 2020) 
612 The results obtained in this study indicated overfishing of the geoduck clam population in Puerto

613 Peñasco, Sonora, in the upper Gulf of California, which had not been identified in the stock

614 assessment previously proposed by the fishery management plan for P. globosa (DOF, 2012).

615 The geoduck clam fishery in Mexico continues to be regulated through a passive management

616 scheme, which is unable to identify the variability in the total biomass or changes in recruitment

617 over time. The ICSA model used in this study was able to evaluate individual growth patterns as

618 well as recruitment, selectivity, harvest rates, and survival rates. Thus, the population dynamics

619 is included in the final estimations of the management quantities, such as biomass-at-shell length

620 (total and vulnerable) and harvest rate-at-shell length. The harvest rate and variability in

621 recruitment between beds have important implications for geoduck clam management and should

622 be considered to avoid serial overfishing, particularly if the populations are structured in small

623 isolated beds, which increases the possibility of overfishing. Therefore, geoduck clam

624 management should include a conservative approach for each fishing area, improving both

625 conservation and fishery objectives to avoid the depletion of P. globosa population.

626

627 Acknowledgments

628

629 This research did not receive any specific funding from agencies in the public, commercial, or 630 not-for-profit sectors. The authors thank the Coops Mar y Tierra del Golfo de Cortéz, Buzos de

631 Puerto Punta Peñasco, Jaiberos y Escameros, and Islas de Sonora for the logistic and field

632 support. Thanks to Daniela Maldonado Enriquez for her support in image editing. Marlene Anaid

633 Luquin-Covarrubias thanks the Consejo Nacional de Ciencia y Tecnología México (CONACyT)

634 for the PhD fellowship (CVU 636852/337484).

635

636 References

637 Andersen, A.M., Jr. (1971). Spawning, growth and spatial distribution of the geoduck clam,

638 Panope generosa (Gould), in Hood Canal, Washington. Ph.D. thesis, University of Washington, 639 Seattle.

640

641 Amezcua-Castro, S., Morales-Bojórquez, E., Arreguín-Sánchez, F., Luquin-Covarrubias, M. A.,

642 García-Borbón, J. A., Cisneros-Montemayor, A. M. (2019). Effects of Serial Depletion on the 
643 Fishery Management of Geoduck Panopea globosa. Journal of Shellfish Research, 38(3), 543644 556. doi: 10.2983/035.038.0305

645

646 Aragón-Noriega, E. A., Calderon-Aguilera, L. E., Pérez-Valencia, S. A. (2015). Modeling 647 growth of the cortes geoduck Panopea globosa from unexploited and exploited beds in the 648 northern Gulf of California. Journal of Shellfish Research, 34(1), 119-127.

649 https://doi.org/10.2983/035.034.0115.

650

651 Aragón-Noriega, E. A. (2015). Size at maturity of the Cortes geoduck Panopea globosa in 652 Central Gulf of California. Hidrobiológica, 25(2), 257-263. doi: 10.15174/au.2015.800.

653

654 Aragón-Noriega, E. A., Alcántara-Razo, E., Calderon-Aguilera, L. E., Sánchez-Fourcade, R. 655 (2012). Status of geoduck clam fisheries in Mexico. Journal of Shellfish Research, 31(3), 733 656 738. http://dx.doi.org/10.2983/035.031.0317.

657

658

Aranceta-Garza, F., Arreguín-Sánchez, F., Ponce-Díaz, G., Seijo, J. C. (2016). Natural mortality 659 of three commercial penaeid shrimps (Litopenaeus vannamei, L. stylirostris and Farfantepenaeus 660 californiensis) of the Gulf of California using gnomonic time divisions. Scientia Marina, 80(2), 661 199-206. doi: http://dx.doi.org/10.3989/scimar.04326.29A

662

663 Arcos-Ortega, F. G., León-Hing, S. J. S., Rodriguez-Jaramillo, C., Burgos-Aceves, M. A., 664 Giffard-Mena, I., García-Esquivel, Z. (2015). Biochemical and histochemical changes associated 665 with gonad development of the Cortez geoduck, Panopea globosa (Dall 1898), from the Gulf of 666 California, Mexico. Journal of Shellfish Research, 34(1), 71-80.

667 https://doi.org/10.2983/035.034.0110.

668

669 Arreguín-Sánchez, F., Arcos-Huitrón, E. (2011). Fishing in Mexico: state of exploitation and use 670 of ecosystems. Hidrobiológica, 21(3), 431-462.

671 
672 Baeta, M., Ramón, M., Galimany, E. (2014). Decline of a Callista chione (Bivalvia: Veneridae)

673 bed in the Maresme coast (northwestern Mediterranean Sea). Ocean \& Coastal Management, 93,

674 15-25. https://doi.org/10.1016/j.ocecoaman.2014.03.001.

675

676 Botsford, L. W., Campbell, A., Miller, R. (2004). Biological reference points in the management

677 of North American sea urchin fisheries. Canadian Journal of Fisheries and Aquatic

678 Sciences, 61(8), 1325-1337. https://doi.org/10.1139/f04-131.

679

680 Branch, T. A., Hilborn, R., Haynie, A. C., Fay, G., Flynn, L., Griffiths, J., Marshall, K. N.,

681 Randall, J. K., Scheuerell, J. M., Ward, E. J., Young, M. (2006). Fleet dynamics and fishermen

682 behavior: lessons for fisheries managers. Canadian Journal of Fisheries and Aquatic

683 Sciences, 63(7), 1647-1668.

684

685 Beverton, R.J.H., and Holt, S.J. (1957). On the dynamics of exploited fish populations. Fish.

686 Invest. Ser. 2 Mar. Fish. G.B. Minist. Agric. Fish. Food No. 19.

687

688 Bureau, D., Hajas, W., Scurry, N. W., Hand, C. M., Dovey, G., Campbell, A. (2002). Age, size

689 structure and growth parameters of geoducks (Panopea abrupta, Conrad 1849) from 34 locations

690 in British Columbia sampled between 1993 and 2000. Canadian Technical Report of Fisheries

691 and Aquatic Sciences, 2413, 84 pp.

692

693 Bureau, D., Hajas, W., Hand C. M., Dovey, G. (2003). Age, size structure and growth parameters

694 of geoducks (Panopea abrupta, Conrad 1849) from seven locations in British Columbia sampled

695 in 2001 and 2002. Canadian Technical Report of Fisheries and Aquatic Sciences, 2494, 29 pp.

696

697 Caddy, J. F. (1996). Modelling natural mortality with age in short-lived invertebrate populations:

698 definition of a strategy of gnomonic time division. Aquatic Living Resources, 9(3), 197-207.

699 Cadrin, S. X., Pastoors, M. A. (2008). Precautionary harvest policies and the uncertainty

700 paradox. Fisheries Research, 94(3), 367-372.

701 
702 Calderon-Aguilera, L. E., Aragón-Noriega, E. A., Morales-Bojórquez, E., Alcántara-Razo, E.,

703 Chávez-Villalba, J. (2014). Reproductive cycle of the geoduck clam Panopea generosa at its

704 southernmost distribution limit. Marine Biology Research, 10(1), 61-72.

705 https://doi.org/10.1080/17451000.2013.793808.

706

707 Calderon-Aguilera, L. E., Aragón-Noriega, E. A., Reyes-Bonilla, H., Paniagua-Chavez, C. G.,

708 Romo-Curiel, A. E., Moreno-Rivera, V. M. (2010a). Reproduction of the Cortes geoduck

709 Panopea globosa (Bivalvia: Hiatellidae) and its relationship with temperature and ocean

710 productivity. Journal of Shellfish Research, 29(1), 135-142.

711 https://doi.org/10.2983/035.029.0107.

712

713 Calderon-Aguilera, L. E., Aragón-Noriega, E. A., Hand, C. M., Moreno-Rivera, V. M. (2010b).

714 Morphometric relationships, age, growth, and mortality of the geoduck clam, Panopea generosa,

715 along the Pacific coast of Baja California, Mexico. Journal of Shellfish Research, 29(2), 319-

716 327. https://doi.org/10.2983/035.029.0206.

717

718 Campbell, A., Ming, M. D. (2003). Maturity and growth of the Pacific geoduck clam, Panopea

719 abrupta, in southern British Columbia, Canada. Journal of Shellfish Research, 22(1), 85-90.

720

721 Campbell, A., Yeung, C. W., Dovey, G., Zhang, Z. (2004). Population biology of the Pacific

722 geoduck clam, Panopea abrupta, in experimental plots, southern British Columbia,

723 Canada. Journal of Shellfish Research, 23(3), 661-674.

724

725 Canales, C. M., Company, J. B., Arana, P. M. (2016). Using a length-based stock assessment

726 model to evaluate population structure hypotheses of nylon shrimp Heterocarpus reedi

727 (Decapoda, Caridea) exploited off central Chile. Fisheries Research, 183, 360-370.

728 https://doi.org/10.1016/j.fishres.2016.06.020

729

730 Cao, J., Chen, Y., Richards, R. A. (2016). Improving assessment of Pandalus stocks using a

731 seasonal, size-structured assessment model with environmental variables. Part I: Model 
732 description and application. Canadian Journal of Fisheries and Aquatic Sciences, 74(3), 349-

733 362. https://doi.org/10.1139/cjfas-2016-0020.

734

735 Carlson, J. K., Cortés, E. (2003). Gillnet selectivity of small coastal sharks off the southeastern

736 United States. Fisheries Research, 60(2-3), 405-414. https://doi.org/10.1016/S0165-

737 7836(02)00135-2.

738

739

Cortez-Lucero, G., Arreola-Lizárraga, J. A., Chávez-Villalba, J., Aragón-Noriega, E. A. (2014).

740

Distribución y abundancia de la almeja de sifón Panopea globosa (Bivalvia: Hiatellidae), en la

741 región central del Golfo de California, México. Hidrobiológica, 24(3), 167-174.

742

743

Cruz-Vásquez, R., Rodríguez-Domínguez, G., Alcántara-Razo, E., Aragón-Noriega, E. A.

744

(2012). Estimation of individual growth parameters of the Cortes geoduck Panopea globosa

745

from the central Gulf of California using a multimodel approach. Journal of Shellfish

746

Research, 31(3), 725-732. doi: 10.2983/035.031.0316

747

748

DOF. 2012. Diario Oficial de la Federación. Miércoles 7 de noviembre de 2012. Segunda

Sección. Plan de Manejo para la Pesquería de Almeja Generosa (Panopea globosa) en las costas

750 de Sonora, México. 23 pp.

751

752

Dowling, N. A., Dichmont, C. M., Haddon, M., Smith, D. C., Smith, A. D. M., Sainsbury, K.

753

(2015). Guidelines for developing formal harvest strategies for data-poor species and

754

fisheries. Fisheries Research, 171, 130-140. https://doi.org/10.1016/j.fishres.2014.09.013.

755

756

Ferreira-Arrieta, A., García-Esquivel, Z., González-Gómez, M. A., Valenzuela-Espinoza, E.

757 (2015). Growth, survival, and feeding rates for the geoduck Panopea globosa during larval

758 development. Journal of Shellfish Research, 34(1), 55-61.

759

https://doi.org/10.2983/035.034.0108.

760 
761 Fitzgerald, S. P., Wilson, J. R., Lenihan, H. S. (2018). Detecting a need for improved

762 management in a data-limited crab fishery. Fisheries Research, 208, 133-144.

763 https://doi.org/10.1016/j.fishres.2018.07.012.

764

765 Fisch, N. C., Bence, J. R., Myers, J. T., Berglund, E. K., Yule, D. L. (2019). A comparison of

766 age-and size-structured assessment models applied to a stock of cisco in Thunder Bay,

767 Ontario. Fisheries Research, 209, 86-100. https://doi.org/10.1016/j.fishres.2018.09.014.

768

769 Fournier, D. A., Skaug, H. J., Ancheta, J., Ianelli, J., Magnusson, A., Maunder, M. N., Nielsen,

770 A., Sibert, J. (2012). AD Model Builder: using automatic differentiation for statistical inference

771 of highly parameterized complex nonlinear models. Optimization Methods and Software, 27(2),

772 233-249. https://doi.org/10.1080/10556788.2011.597854

773

774 Goodwin, C. L., Pease, B. (1989). Species Profiles: life histories and environmental requirements

775 of coastal fishes and invertebrates (Pacific Northwest). Pacific Geoduck clam. U.S. Fish. Wildl.

776 Serv. Biol. Rep. 82(11.120). U.S. Army Corps of Engineers, TR EL-82-4. 14 pp.

777

778 Goodwin. C. L., Pease, B. C. (1991). Geoduck (Panopea abrupta Conrad, 1894) size, density,

779 and quality as related to various environmental parameters in Puget Sound, Washington. Journal

780 of Shellfish Research, 10(1), 65-77.

781

782 González-Peláez, S. S., Morales-Bojórquez, E., Lluch-Cota, D. B., Bautista-Romero, J. J.

783 (2015a). Application of a gnomonic model to estimate the life span and natural mortality in

784 Panopea globosa. Journal of Shellfish Research, 34(1), 113-118.

785 https://doi.org/10.2983/035.034.0114.

786

787 González-Peláez, S. S., Morales-Bojórquez, E., Lluch-Cota, D. B., Lluch-Cota, S. E., Bautista-

788 Romero, J. J. (2015b). Modeling geoduck growth: multimodel inference in Panopea globosa

789 from the southwestern Baja California Peninsula, Mexico. Journal of Shellfish Research, 34(1),

790 101-112. https://doi.org/10.2983/035.034.0113.

791 
792 González-Peláez, S. S., Leyva-Valencia, I., Lluch-Cota, D. B. (2013). Distribution limits of the

793 geoduck clams Panopea generosa and P. globosa on the Pacific coast of

794 Mexico. Malacologia, 56(2), 85-94. https://doi.org/10.4002/040.056.0206.

795

796 Gribben, P. E., Creese, R. G. (2003). Protandry in the New Zealand geoduck, Panopea zelandica

797 (Mollusca, Bivalvia). Invertebrate Reproduction and Development, 44(2-3), 119-129. doi:

$798 \quad 10.1080 / 07924259.2003 .9652562$

799

800 Gribben, P. E., Heasman, K. G. (2015). Developing Fisheries and Aquaculture Industries for

801 Panopea zelandica in New Zealand. Journal of Shellfish Research, 34(1), 5-10.

802 https://doi.org/10.2983/035.034.0103.

803

804 Gunderson, D. R. (1980). Using rK selection theory to predict natural mortality. Canadian

805 Journal of Fisheries and Aquatic Sciences, 37(12), 2266-2271.

806

807 Harris, B. P., Adams, C. F., \& Stokesbury, K. D. (2018). Sea scallops exhibit strong local

808 spatiotemporal structure associated with seabed stability and high flows. Ecosphere, 9(3), $809 \mathrm{e} 02133$.

810

811 Hart, D. R. (2003). Yield-and biomass-per-recruit analysis for rotational fisheries, with an

812 application to the Atlantic sea scallop (Placopecten magellanicus). Fishery Bulletin, 101(1), 4481357.

814

815 Hart, D. R. (2001). Individual-based yield-per-recruit analysis, with an application to the Atlantic 816 sea scallop, Placopecten magellanicus. Canadian Journal of Fisheries and Aquatic

817 Sciences, 58(12), 2351-2358. DOI: 10.1139/cjfas-58-12-2351

818

819 Hidalgo-de-la-Toba, J. A., Morales-Bojórquez, E., González-Peláez, S. S., Bautista-Romero, J.

820 J., Lluch-Cota, D. B. (2018). Modeling the temporal periodicity of growth increments based on 821 harmonic functions. PloS one, 13(4), e0196189. https://doi.org/10.1371/journal.pone.0196189. 822 
823 Hilborn, R., Orensanz, J. L., Parma, A. M. (2005). Institutions, incentives and the future of

824 fisheries. Philosophical Transactions of the Royal Society of London B: Biological

825 Sciences, 360(1453), 47-57. https://doi.org/10.1098/rstb.2004.1569.

826

827 Hilborn, R., Walters, C. J. (1992). Quantitative fisheries stock assessment: choice, dynamics and 828 uncertainty. New York, NY: Chapman and Hall. 521 pp.

829

830 Hoenig, J. M. (1983). Empirical use of longevity data to estimate mortality rates. Fishery

831 Bulletin, 82(1), 898-903.

832

833 Hoffman, A., Bradbury A., Goodwin, C. L.. (2000). Modeling geoduck, Panopea abrupta

834 (Conrad, 1849) population dynamics: I. Growth. Journal of Shellfish Research, 19(1), 57-62.

835

836 Jensen, A. L. (1996). Beverton and Holt life history invariants result from optimal trade-off of

837 reproduction and survival. Canadian Journal of Fisheries and Aquatic Sciences, 53(4), 820-822.

838

839 Karpov, K., Haaker, P., Taniguchi, I., Rogers-Bennett, L. (2000). Serial depletion and the

840 collapse of the California abalone (Haliotis spp.) fishery. In: Campell, A. (Eds.), Workshop on

841 rebuilding abalone stocks in British Columbia. Canadian Special Publication of Fisheries and

842 Aquatic Sciences, 130, 11-24.

843

844 Khan, A. (2006). Sustainability challenges in the geoduck clam fishery of British Columbia:

845 policy perspectives. Coastal Management, 34(4), 443-453.

846 https://doi.org/10.1080/08920750600860548.

847

848 Kirby, M. X. (2004). Fishing down the coast: historical expansion and collapse of oyster

849 fisheries along continental margins. Proceedings of the National Academy of Sciences, 101(35),

850 13096-13099. https://doi.org/10.1073/pnas.0405150101.

851

852 Law, R. (2000). Fishing, selection, and phenotypic evolution. ICES Journal of Marine

853 Science, 57(3), 659-668. https://doi.org/10.1006/jmsc.2000.0731. 
854 Legault, C. M., Restrepo, V. R. (1998). A flexible forward age-structured assessment

855 program. ICCAT. Col. Vol. Sci. Pap, 49, 246-253.

856

857 Leyva-Valencia, I., Cruz-Hernández, P., Álvarez-Castañeda, S. T., Rojas-Posadas, D. I., Correa858 Ramírez, M. M., Vadopalas, B., Lluch-Cota, D. B. (2015). Phylogeny and phylogeography of the 859 geoduck Panopea (Bivalvia: Hiatellidae). Journal of Shellfish Research, 34(1), 11-20.

860 https://doi.org/10.2983/035.034.0104.

861

862 Luquin-Covarrubias, M. A., Morales-Bojórquez, E., González-Peláez, S. S., Hidalgo-De-La-

863 Toba, J. Á., Lluch-Cota, D. B. (2016). Modeling of growth depensation of geoduck clam

864 Panopea globosa based on a multimodel inference approach. Journal of Shellfish

865 Research, 35(2), 379-387. https://doi.org/10.2983/035.035.0212.

866

867 Luquin-Covarrubias, M. A., Morales-Bojórquez, E., González-Peláez, S. S., Lluch-Cota, D. B. 868 (2016). Joint likelihood function based on multinomial and normal distributions for analyzing the 869 phenotypic growth variability of geoduck clam Panopea globosa. California Cooperative 870 Oceanic Fisheries Investigations Report Reports, 57, 151-162.

871

872 McCormick, T. (2000). Abalone (Haliotis spp.) aquaculture: present status and a stock 873 enhancement tool. In: Campbell, A. (Eds), Workshop on rebuilding abalone stocks in British 874 Columbia. Canadian Special Publication of Fisheries and Aquatic Sciences, 130, 55-60. 875

876 Maeda-Martínez, A. N., Reynoso-Granados, T., Sólis-Marín, F., Leija-Tristán, A., 877 Aurioles-Gamboa, D., Salinas-Zavala, C. A., Felix-Pico, E. (1993). A model to explain the 878 formation of catarina scallop, Argopecten circularis (Sowerby, 1835), beds, in Magdalena Bay, 879 Mexico. Aquaculture Research, 24(3), 323-339. https://doi.org/10.1111/j.1365880 2109.1993.tb00554.x.

881

882 Mangin, T., Cisneros-Mata, M. Á., Bone, J., Costello, C., Gaines, S. D., McDonald, G., 883 Rodriguez, L., Strauss, C. K., Zapata, P. (2018). The cost of management delay: The case for 884 reforming Mexican fisheries sooner rather than later. Marine Policy, 88, 1-10. 
885 Martínez-Aguilar, S., Arreguín-Sánchez, F., Morales-Bojórquez, E. (2005). Natural mortality 886 and life history stage duration of Pacific sardine (Sardinops caeruleus) based on gnomonic time 887 divisions. Fisheries Research, 71(1), 103-114.

888

889 Maunder, M. N., Punt, A. E. (2013). A review of integrated analysis in fisheries stock

890 assessment. Fisheries Research, 142, 61-74.

891

892 Megrey, B. A. (1989). Review and comparison of age-structured stock assessment models from 893 theoretical and applied points of view. American Fisheries Society Symposium, 6, 8-48.

894

895 Morales-Bojórquez, E., Aragón-Noriega, E. A., Aguirre-Villaseñor, H., Calderon-Aguilera, L. 896 E., Zepeda-Benitez, V. Y. (2015). Selection of models to predict Panopea globosa growth: 897 application of a mixture probability distribution function. Journal of Shellfish Research, 34(1), 898 129-137. https://doi.org/10.2983/035.034.0116.

899

900 Morales-Bojórquez, E., López-Martínez, J., Beléndez-Moreno, L. F. J. (2013). Estimating

901 biomass, recruitment, and harvest rate for the Pacific yellowleg shrimp Farfantepenaeus

902 californiensis from a size-based model. Journal of Shellfish Research, 32(3), 815-824.

903 https://doi.org/10.2983/035.032.0325.

904

905 Morales-Bojórquez, E., Nevárez-Martínez, M. O. (2010). Catch-at-size analysis for Dosidicus 906 gigas in the central Gulf of California, Mexico in 1996-2002. Fisheries Research, 106(2), 214907 221. https://doi.org/10.1016/j.fishres.2010.08.004.

908

909 Morales-Bojórquez, E., Muciño-Díaz, M. O., Vélez-Barajas, J. A. (2008). Analysis of the decline

910 of the abalone fishery (Haliotis fulgens and H. corrugata) along the westcentral coast of the Baja

911 California peninsula, Mexico. Journal of Shellfish Research, 27(4), 865-870.

912 https://doi.org/10.2983/0730-8000(2008)27[865:AOTDOT]2.0.CO;2.

913 
914 Munguia-Vega, A., Leyva-Valencia, I., Lluch-Cota, D. B., Cruz-Hernandez, P. (2015). Genetic

915 structure of the Cortes geoduck Panopea globosa Dall, 1898, from the Mexican

916 Northwest. Journal of Shellfish Research, 34(1), 153-161.

917 https://doi.org/10.2983/035.034.0119.

918

919 Muse, B. (1998). Management of the British Columbia geoduck fishery: CFEC 98-3N. Juneau,

920 Alaska: Alaska Commerical Fisheries Entry Commission, 23 pp.

921

922 Myers, R. (2002). Recruitment: understanding density-dependence in fish populations. In: Hart,

923 P. J. B., Reynolds, J. D. (Eds), Handbook of fish biology and fisheries. Oxford: Blackwell

924 Publishing. Fish biology, 1, 123-148. https://doi.org/10.1002/9780470693803.ch6.

925

926 Myers, R. A., Fuller, S. D., Kehler, D. G. (2000). A fisheries management strategy robust to

927 ignorance: rotational harvest in the presence of indirect fishing mortality. Canadian Journal of

928 Fisheries and Aquatic Sciences, 57(12), 2357-2362.

929

930 Nadon, M. O., Ault, J. S. (2016). A stepwise stochastic simulation approach to estimate life

931 history parameters for data-poor fisheries. Canadian Journal of Fisheries and Aquatic

932 Sciences, 73(12), 1874-1884.

933

934 Neter, J., Kutner, M. H., Nachtsheim, C. J., Wasserman, W. (1996). Applied linear statistical

935 models. Chicago: Irwin. 318 pp.

936

937 Ochoa-Araiza, G., Barajas-Girón, M. P., Jiménez-Llanos, R. V., Larios-Castro, E., González-

938 Corona, M. E. (2014). Evaluación de almeja generosa en los bancos 1 y 2 de la S.C.P.P. Buzos

939 de Puerto Punta Peñasco, S.C. de R.L. frente al estero La Pinta en Puerto Peñasco Sonora,

940 durante el mes de octubre de 2014. Informe técnico. Instituto Nacional de Pesca. Centro

941 Regional de Investigación Pesquera en Guaymas. 26 pp.

942

943 Ochoa-Araiza, G., Barajas-Girón, M. P., Jiménez-Llanos, R. V., Larios-Castro, E., González-

944 Corona, M. E. (2015). Evaluación de almeja generosa en el polígono solicitado por la S.C.P.P. 
945 Jaiberos y Escameros, S.C. de R.L. realizado en noviembre de 2015. Informe técnico. Instituto

946 Nacional de Pesca. Centro Regional de Investigación Pesquera en Guaymas. 28 pp.

947

948 Orensanz J. M., Parma, A. M. Smith, S. J. (2016). Scallops: Biology, Ecology, Aquaculture, and

949 Fisheries. In. Shumway, S. E, Parsons G. J. ed. Dynamics, Assessment, and Management of

950 Exploited Natural Scallop Populations. Amsterdam, Netherlands: Elsevier. Third edition.. pp.

$951611-676$.

952

953 Orensanz, J. M., Hand, C. M., Parma, A. M., Valero, J., Hilborn, R. (2004). Precaution in the

954 harvest of Methuselah's clams the difficulty of getting timely feedback from slow-paced

955 dynamics. Canadian Journal of Fisheries and Aquatic Sciences, 61(8), 1355-1372.

956 https://doi.org/10.1139/f04-136.

957

958 Orensanz, J. M., Armstrong, J., Armstrong, D., Hilborn, R. (1998). Crustacean resources are

959 vulnerable to serial depletion - the multifaceted decline of crab and shrimp fisheries in the

960 greater Gulf of Alaska. Reviews in Fish Biology and Fisheries, 8(2), 117-176.

961

962 Pauly, D. (1980). On the interrelationships between natural mortality, growth parameters, and

963 mean environmental temperature in 175 fish stocks. ICES journal of Marine Science, 39(2), 175-

964192.

965

966 Pérez-Valencia, S. A., Aragón-Noriega, E. A. (2013). Age and growth of the Cortes geoduck

967 Panopea globosa (Dall, 1898) in the upper Gulf of California. Indian Journal of Geo-Marine

968 Sciences, 42(2), 201-205.

969

970 Pezzuto, P. R., Borzone, C. A. (2004). The collapse of the scallop Euvola ziczac (Linnaeus,

971 1758) (Bivalvia: Pectinidae) fishery in Brazil: changes in distribution and relative abundance

972 after 23 years of exploitation. Brazilian Journal of Oceanography, 52(3-4), 225-236.

973 http://dx.doi.org/10.1590/S1679-87592004000300005.

974 
975 Punt, A. E., Huang, T., Maunder, M. N. (2013). Review of integrated size-structured models for

976 stock assessment of hard-to-age crustacean and mollusc species. ICES Journal of Marine

977 Science, 70(1), 16-33.

978

979

Ramírez-Mendoza, R., Álvarez, L. G. (2009) Batimetría del área de extracción de la almeja de

980 sifón Panopea spp. en la costa norte de Sonora. Informe Técnico. Departamento de Oceanografía

981 Física. Centro de Investigación Científica y de Educación Superior de Ensenada, Baja California. $9828 \mathrm{pp}$.

983

984 Ramírez-Rodríguez, M., Ojeda-Ruíz, M. Á. (2012). Spatial management of small-scale fisheries 985 on the west coast of Baja California Sur, Mexico. Marine policy, 36(1), 108-112.

986

987

Ramírez-Rodríguez, M., Arreguín-Sanchez, F. A. (2003). Life history stage duration and natural

988 mortality for the pink shrimp Farfantepenaeus duorarum (Burkenroad, 1939) in the southern Gulf of Mexico, using the gnomonic model for time division. Fisheries Research, 60(1), 45-51.

990

991

Ricker W. E. (1954). Stock and recruitment. Journal of the Fisheries Research Board of Canada, 992 11(4), 559-623 doi: 10.1139/f54-039.

993

994

Ricker, W. E. (1975). Computation and interpretation of biological statistics of fish populations. Bulletin. Fisheries Research Board of Canada, 191, 1-382.

996

997

Romero-Gallardo, S., Velázquez-Abunader, I., López-Rocha, J. A., Garza-Gisholt, E. (2018).

998

Natural mortality estimates throughout the life history of the sea cucumber Isostichopus

Badionotus (Holothuroidea: Aspidochirotida). PeerJ, 6, e5235; doi: 10.7717/peerj.5235. Series, 111, 29-39. 
1005 Suárez-Moo, P. J., Gilbert-Horvath, E. A., Vadopalas, B., Calderon-Aguilera, L. E., Garza, J. C.,

1006 Rocha-Olivares, A. (2016). Genetic homogeneity of the geoduck clam Panopea generosa in the

1007 northeast Pacific. Biochemical Systematics and Ecology, 65, 66-71.

1008 https://doi.org/10.1016/j.bse.2016.02.003.

1009

1010 Sullivan, P. J., Lai, H. L., Gallucci, V. F. (1990). A catch-at-length analysis that incorporates a

1011 stochastic model of growth. Canadian Journal of Fisheries and Aquatic Sciences, 47(1), 184-

1012 198. https://doi.org/10.1139/f90-021.

1013

1014 Tracey, S. R., Lyle, J. M. (2011). Linking scallop distribution and abundance with fisher

1015 behaviour: implication for management to avoid repeated stock collapse in a recreational

1016 fishery. Fisheries Management and Ecology, 18(3), 221-232.

1017 https://doi.org/10.1111/j.1365-2400.2010.00775.x.

1018

1019 Valero, J. L., Hand, C., Orensanz, J. M., Parma, A. M., Armstrong, D., Hilborn, R. (2004).

1020 Geoduck (Panopea abrupta) recruitment in the Pacific Northwest: long-term changes in relation

1021 to climate. California Cooperative Oceanic Fisheries Investigations Report, 45, 80-86.

1022

1023 Zhang, Z., Campbell, A. (2004). Natural mortality and recruitment rates of the Pacific geoduck

1024 clam (Panopea abrupta) in experimental plots. Journal of Shellfish Research, 23(3), 675-682.

1025

1026

Zhang, Z., Hand, C. (2006). Recruitment patterns and precautionary exploitation rates for

1027 geoduck (Panopea abrupta) populations in British Columbia. Journal of Shellfish

1028 Research, 25(2), 445-453. https://doi.org/10.2983/0730-8000(2006)25[445:RPAPER]2.0.CO;2.

1029

1030 List of figures

1031

1032 Figure 1. Study area for the geoduck clam Panopea globosa off Puerto Peñasco, Sonora, 1033 Mexico. The figure was created and edited by Daniela Maldonado Enriquez (CIBNOR SC). 
1035 Figure 2. Catch-at-shell length analysis for the geoduck clam Panopea globosa. The line is the

1036 ICSA model fitted to the observed catch (bars). A) 2010, B) 2011, C) 2012, D) 2014, E) 2015, 1037 and F) 2016.

1038

Figure 3. Recruitment-at-shell length estimated for geoduck clam Panopea globosa in Puerto Peñasco, Sonora. A) time period from 2010-2012, and B) time period from 2014-2016.

Figure 4. Fishing mortality-at-shell length estimated for the geoduck clam Panopea globosa in Puerto Peñasco, Sonora. A) time period from 2010-2012, and B) time period from 2014-2016.

Figure 5. Selectivity-at-shell length estimated for the geoduck clam Panopea globosa in Puerto Peñasco, Sonora.

Figure 6. Harvest rate-at-shell length estimated for the geoduck clam Panopea globosa smaller than the minimum legal shell length of $130 \mathrm{~mm}$. A) time period from 2010-2012, and B) time period from 2014-2016.

1051

Figure 7. Harvest rate-at-shell length estimated for the geoduck clam Panopea globosa larger than minimum legal shell length of $130 \mathrm{~mm}$. A) time period from 2010-2012, and B) time period 1054 from 2014-2016.

1055

Figure 8. Total biomass-at-shell length estimated for the geoduck clam Panopea globosa in Puerto Peñasco, Sonora. A) time period from 2010-2012, and B) time period from 2014-2016.

Figure 9. Vulnerable biomass-at-shell length estimated for the geoduck clam Panopea globosa

1060 in Puerto Peñasco, Sonora. A) time period from 2010-2012, and B) time period from 2014-2016.

1062 Figure 10. Spatiotemporal changes in the fishing area of the geoduck clam Panopea globosa 1063 from 2009 to 2016 . To find the coverage of a fishing area, the station positions were loaded into 1064 GIS software; the boundary stations were traced, and the enclosed areas were calculated $\left(\mathrm{km}^{2}\right)$ 
1065 (Ochoa-Araiza et al., 2014, 2015). A) 2009, B) 2010, C) 2011, D) 2012, E) 2013, and F) 20141066 2016. The figure was created and edited by Daniela Maldonado Enriquez (CIBNOR SC). 1067

1068 Appendix A1. Changes and expansion of the fishing area $\left(\mathrm{km}^{2}\right)$ of the geoduck clam Panopea 1069 globosa in Puerto Peñasco, Sonora. 


\section{Table $\mathbf{1}$ (on next page)}

Table 1. Symbols and descriptions of parameters and variables used in the ICSA model. 
1 Table 1. Symbols and descriptions of parameters and variables used in the ICSA model.

\begin{tabular}{|c|c|}
\hline Symbol & Description \\
\hline 1 & Shell length class \\
\hline$t$ & Time (years) \\
\hline$l^{\prime}$ & Range of shell length classes \\
\hline$t^{\prime}$ & Initial time period \\
\hline $1_{t}$ & Shell length of geoduck clam at time $t$ \\
\hline $1_{t+1}$ & Shell length of geoduck clam at time $t+1$ \\
\hline $\mathrm{Z}_{1, \mathrm{t}}$ & Total mortality at shell length $l$ and time $t$ \\
\hline $\mathrm{F}_{1, \mathrm{t}}$ & Separable fishing mortality at shell length $l$ and time $t$ \\
\hline $\mathrm{M}_{1, \mathrm{t}}$ & Constant natural mortality at shell length $l$ and time $t$ \\
\hline $\mathrm{N}_{1, \mathrm{t}}$ & Abundance of geoducks at shell length $l$ and time $t$ \\
\hline $\mathrm{N}_{l, t^{\prime}}$ & Abundance of geoducks at shell length $l$ and later time $t$ \\
\hline $\mathrm{N}_{l, t}^{\prime}$ & Total abundance of geoduck at length $l^{\prime}$ and $t^{\prime}$ \\
\hline $\mathrm{C}_{1, \mathrm{t}}$ & Observed catch-at-shell length $l$ and time $t$ \\
\hline$\overline{\mathrm{C}}_{1, \mathrm{t}}$ & Estimated catch-at-shell length $l$ and time $t$ \\
\hline$\mu_{1, \mathrm{t}}$ & Harvest rate at shell length $l$ and time $t$ \\
\hline $\mathrm{N}_{0}$ & Initial population abundance \\
\hline $\mathrm{N}_{1,0}$ & Initial abundance of geoducks at shell length $l$ and $t=0$ \\
\hline$\hat{\mathrm{N}}_{1,0}$ & Initial estimated abundance of geoduck at shell length $l$ and $t=0$ \\
\hline $\mathrm{P}_{1}$ & Proportion of geoducks at shell length $l$ \\
\hline $\mathrm{s}_{1}$ & Estimated relative selectivity at shell length $l$ \\
\hline$f_{t}$ & Full-recruitment fishing mortality rate at time $t$ \\
\hline$\alpha_{\mathrm{s}}$ & Selectivity parameter of gamma distribution density function \\
\hline$\beta_{\mathrm{s}}$ & Selectivity parameter of gamma distribution density function \\
\hline $\mathrm{s}_{\mathrm{o}, 1}$ & Observed relative selectivity at shell length $l$ \\
\hline $\mathrm{G}_{1,1+1}$ & Growth matrix at shell length $l$ and $l+1$ \\
\hline $\mathrm{S}_{1, \mathrm{t}}$ & Survival matrix at shell length $l$ and time $t$ \\
\hline $\mathrm{T}_{1, \mathrm{t}}$ & Transition matrix at shell length $l$ and time $t$ \\
\hline$\Delta_{l}$ & Growth increments at shell length $l$ \\
\hline $\bar{\Delta}_{l}$ & Mean growth increment at shell length $l$ \\
\hline$L_{\infty}$ & Asymptotic shell length \\
\hline $1_{*}$ & Midlength at shell length $l$ \\
\hline $\mathrm{k}$ & Growth rate \\
\hline$\alpha_{1}$ & Growth parameter of gamma distribution density function at shell length $l$ \\
\hline$\beta_{\mathrm{g}}$ & Growth parameter of gamma distribution density function \\
\hline $\mathrm{R}_{1, \mathrm{t}}$ & Recruitment to the fishery at shell length $l$ and time $t$ \\
\hline $\mathrm{R}_{\mathrm{t}}$ & Time-dependent variable of recruitment \\
\hline$\varphi_{1}$ & Shell length-dependent variable of recruitment \\
\hline$\alpha_{\mathrm{r}}$ & Recruitment parameter of gamma distribution density function \\
\hline$\beta_{\mathrm{r}}$ & Recruitment parameter of gamma distribution density function \\
\hline $\mathrm{TB}_{1}$ & Total biomass-at-shell length \\
\hline
\end{tabular}




\begin{tabular}{l|l}
\hline $\mathrm{VB}_{1}$ & Vulnerable biomass-at-shell length \\
$\omega_{1}$ & Expected weight of geoduck at shell length $l$ \\
$\alpha$ & Parameter of weight-length relationship \\
$\beta$ & Parameter of weight-length relationship \\
\hline
\end{tabular}

2 


\section{Table 2 (on next page)}

Management quantities estimated from ICSA model

Management quantities estimated for the population of the geoduck clam Panopea globosa in Puerto Peñasco, Sonora. 
1 Table 2. Management quantities estimated for the population of the geoduck clam Panopea globosa in

2 Puerto Peñasco, Sonora.

\begin{tabular}{lcccccc}
\hline Management quantities & $\mathbf{2 0 1 0}$ & $\mathbf{2 0 1 1}$ & $\mathbf{2 0 1 2}$ & $\mathbf{2 0 1 4}$ & $\mathbf{2 0 1 5}$ & $\mathbf{2 0 1 6}$ \\
\hline Total abundance $(\mathrm{N} \mathrm{x} \mathrm{106)}$ & 4.63 & 3.01 & 1.03 & 2.88 & 4.72 & 5.15 \\
Total biomass (t) & 3,262 & 2,517 & 1,130 & 4,801 & 4,870 & 3,619 \\
Vulnerable biomass (t) & 672 & 555 & 480 & 2,820 & 2,189 & 1,104 \\
\hline
\end{tabular}

3 


\section{Table 3(on next page)}

Parameters optimized using GRG algorithm

Parameters and RSS estimated by the ICSA model for the geoduck clam Panopea globosa. 
1 Table 3. Parameters and RSS estimated by the ICSA model for the geoduck clam Panopea globosa.

\begin{tabular}{ccccccc}
\hline Parameters & $\mathbf{2 0 1 0}$ & $\mathbf{2 0 1 1}$ & $\mathbf{2 0 1 2}$ & $\mathbf{2 0 1 4}$ & $\mathbf{2 0 1 5}$ & $\mathbf{2 0 1 6}$ \\
\hline$\hat{N}_{l, 0} \times 10^{6}$ & 1.81 & 0.83 & 0.69 & 1.68 & 2.82 & 2.03 \\
$R_{t} \times 10^{6}$ & 20.53 & 22.12 & 6.04 & 41.63 & 31.05 & 28.12 \\
$\alpha_{r}$ & 14.97 & 12.11 & 9.64 & 6.48 & 9.69 & 13.27 \\
$\beta_{r}$ & 5.26 & 6.68 & 8.12 & 13.11 & 8.38 & 6.00 \\
$\alpha_{s}$ & 56.23 & 49.92 & 60.78 & 46.46 & 40.10 & 37.61 \\
$\beta_{s}$ & 3.16 & 3.58 & 2.93 & 3.83 & 4.56 & 4.73 \\
$\beta_{g}$ & 0.20 & 0.50 & 0.15 & 0.13 & 0.31 & 0.61 \\
$R S S$ & 6.15 & 6.78 & 4.07 & 4.12 & 0.05 & 1.54 \\
\hline
\end{tabular}

2 
Figure 1

Study area for the geoduck clam Panopea globosa off Puerto Peñasco, Sonora, Mexico.

The figure was created and edited by Daniela Maldonado Enriquez (CIBNOR SC).

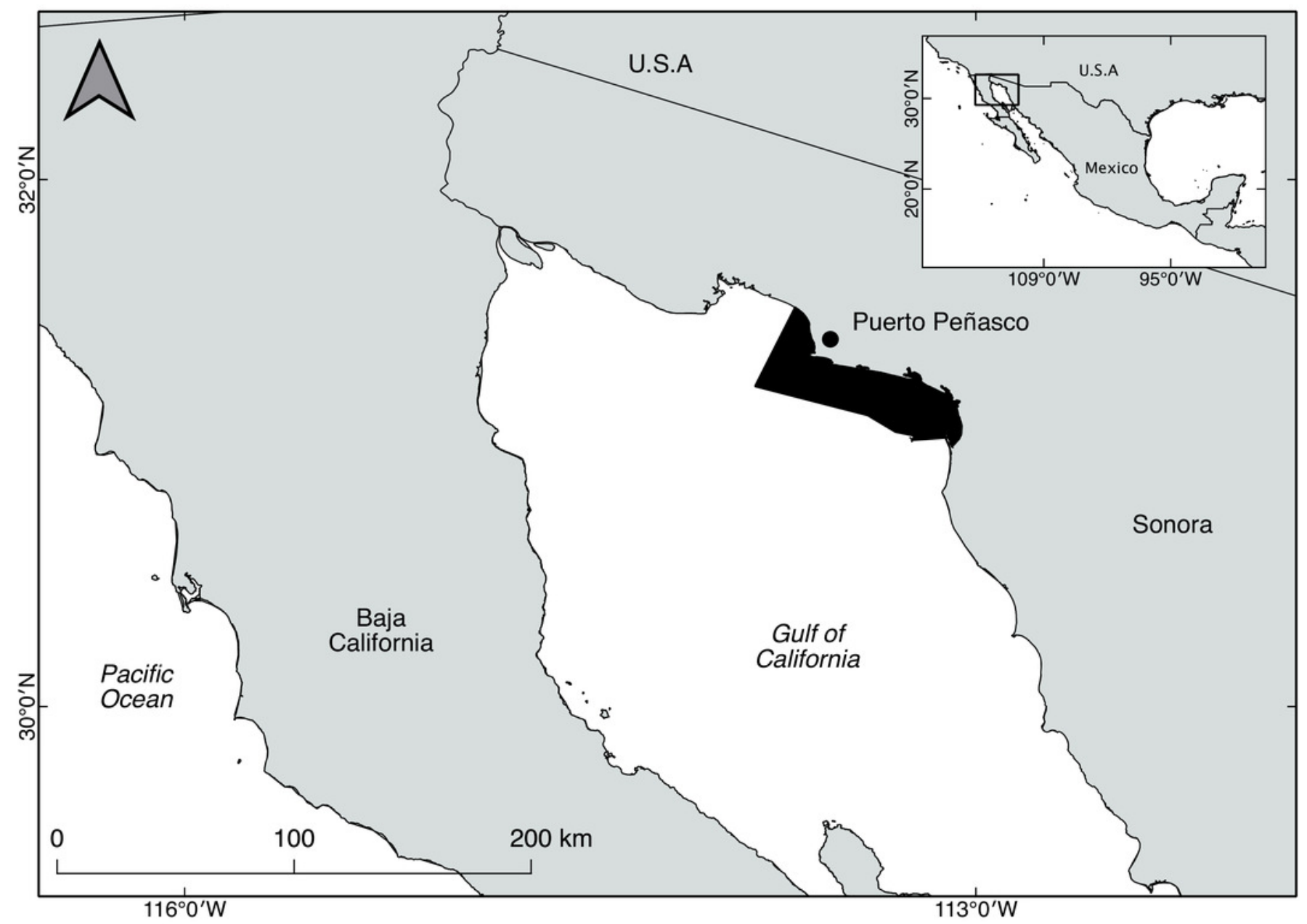


Figure 2

Catch-at-shell length analysis for the geoduck clam Panopea globosa. The line is the ICSA model fitted to the observed catch (bars).

A) 2010, B) 2011, C) 2012, D) 2014, E) 2015, and F) 2016.
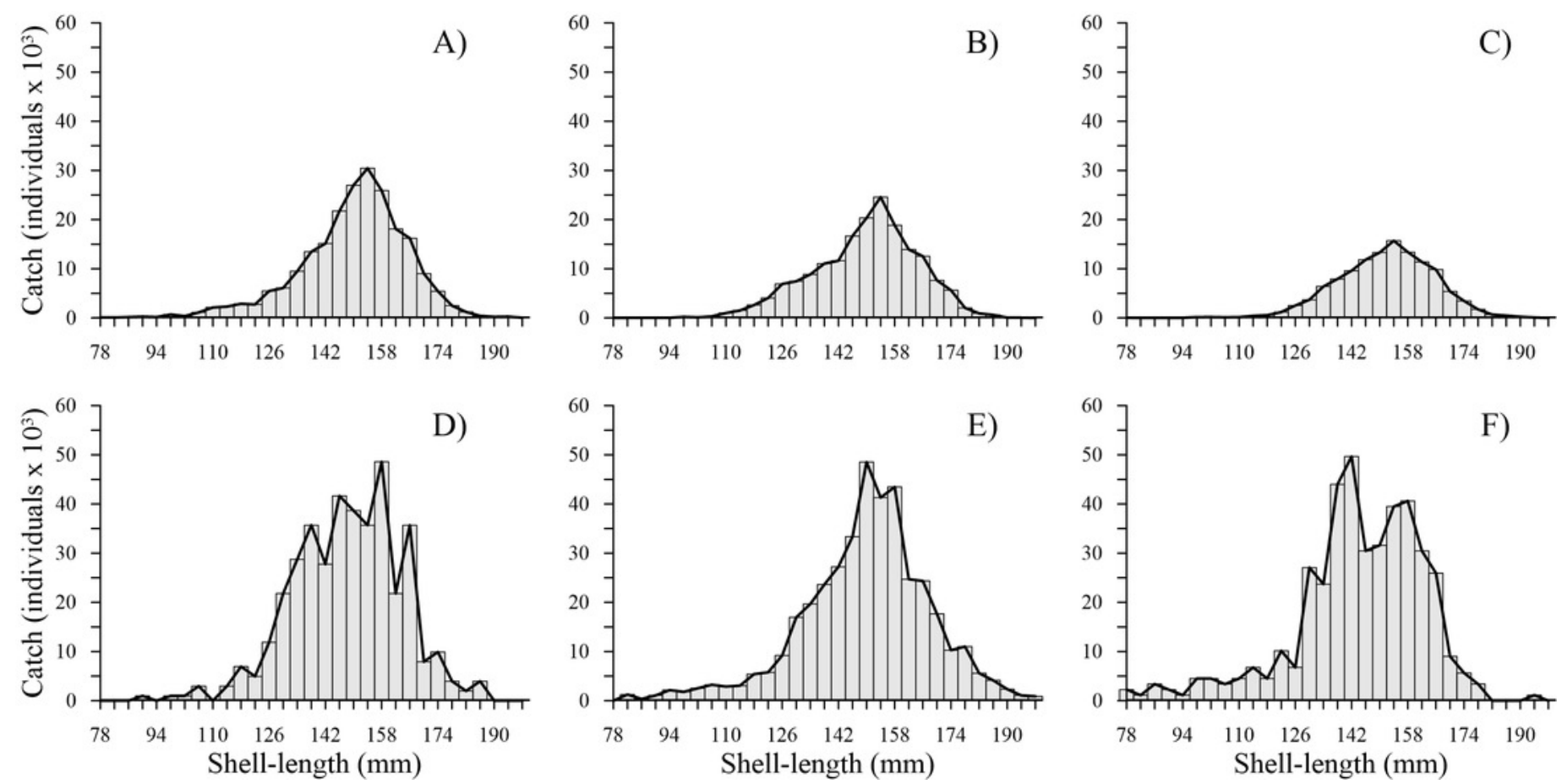
Figure 3

Recruitment-at-length estimated for geoduck clam Panopea globosa in Puerto Peñasco, Sonora
A) time period from 2010-2012, and B) time period from 2014-2016. 

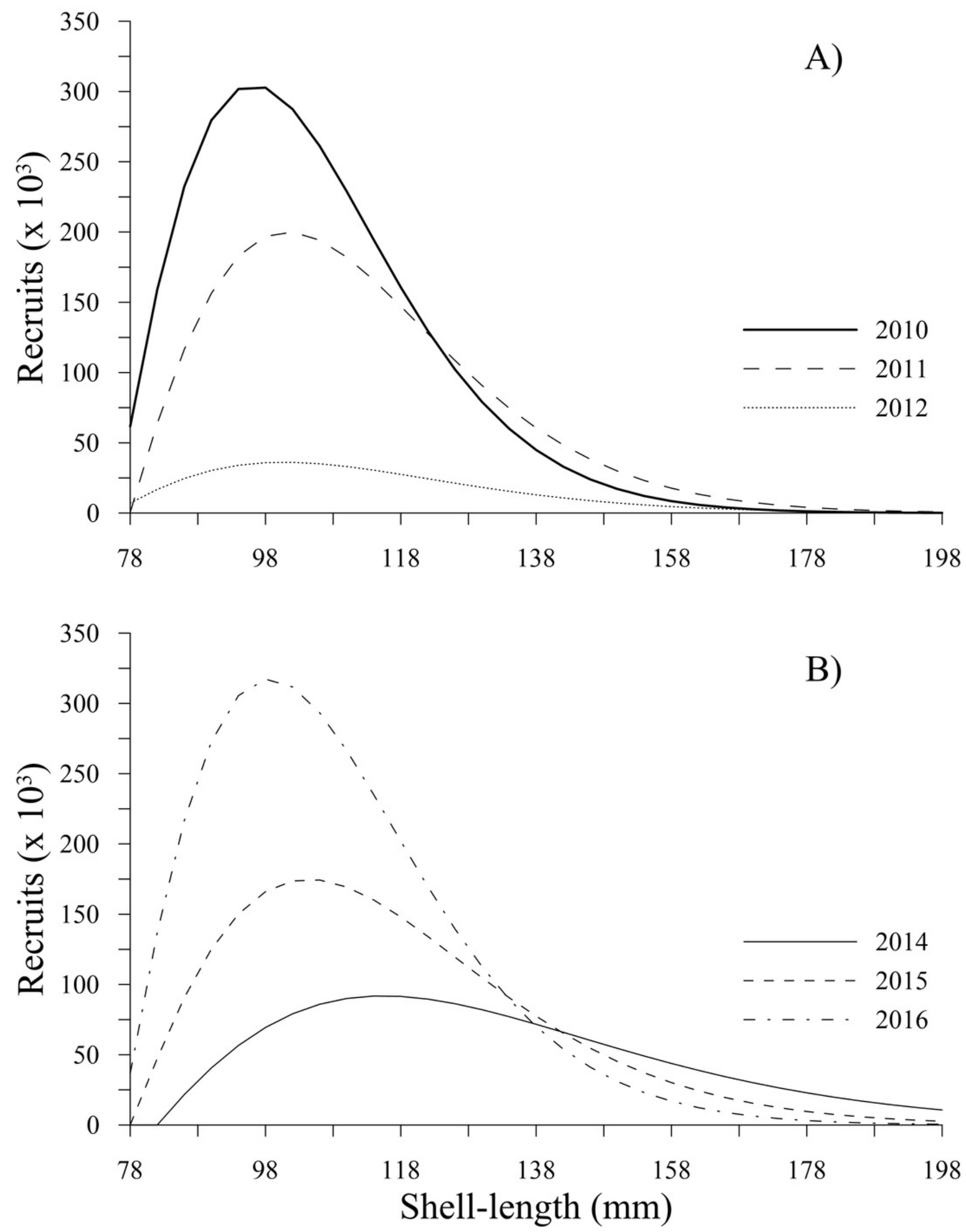
Figure 4

Fishing mortality-at-shell length estimated for the geoduck clam Panopea globosa in Puerto Peñasco, Sonora.
A) time period from 2010-2012, and B) time period from 2014-2016. 

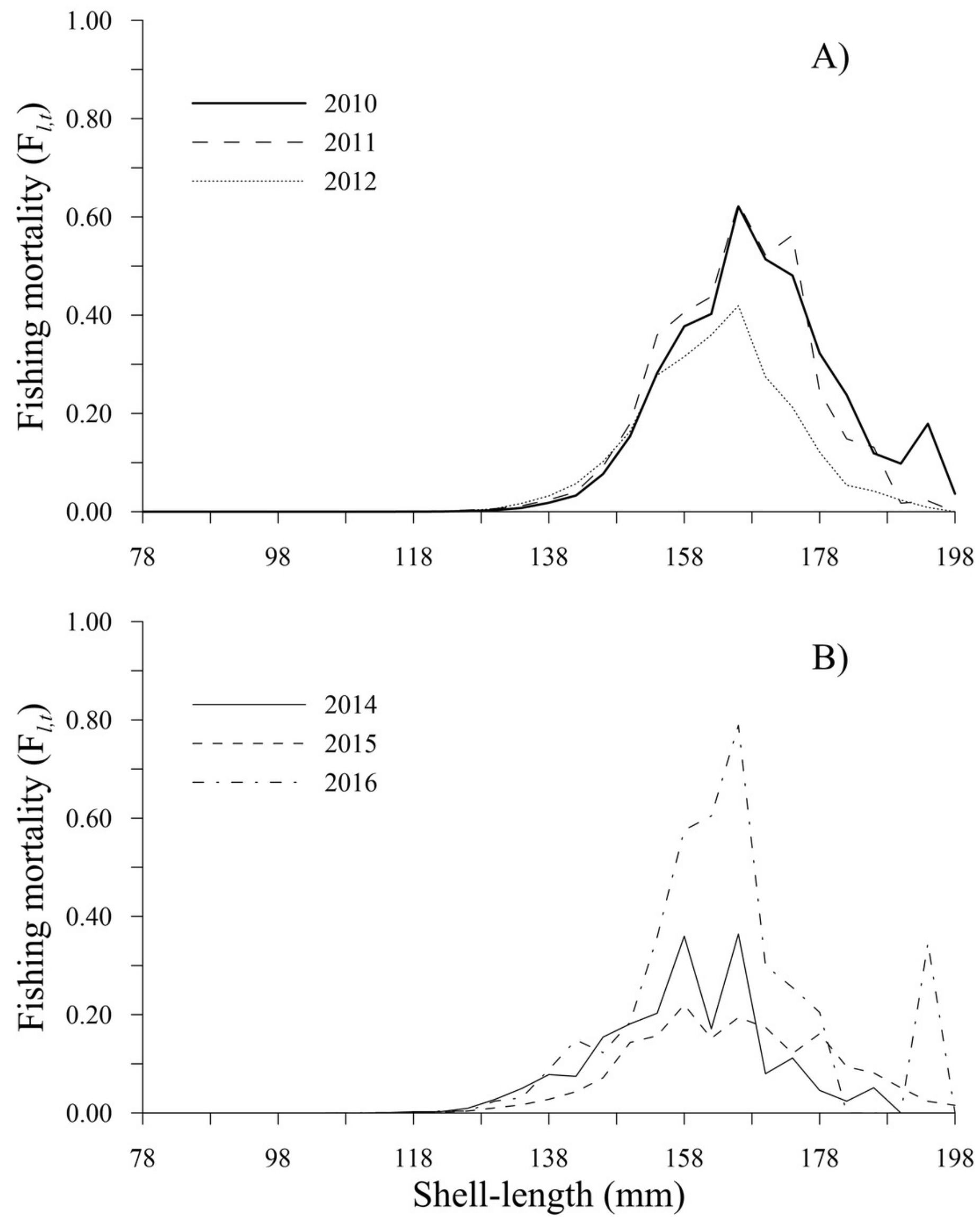
Figure 5

Selectivity-at-shell length estimated for the geoduck clam Panopea globosa in Puerto Peñasco, Sonora.

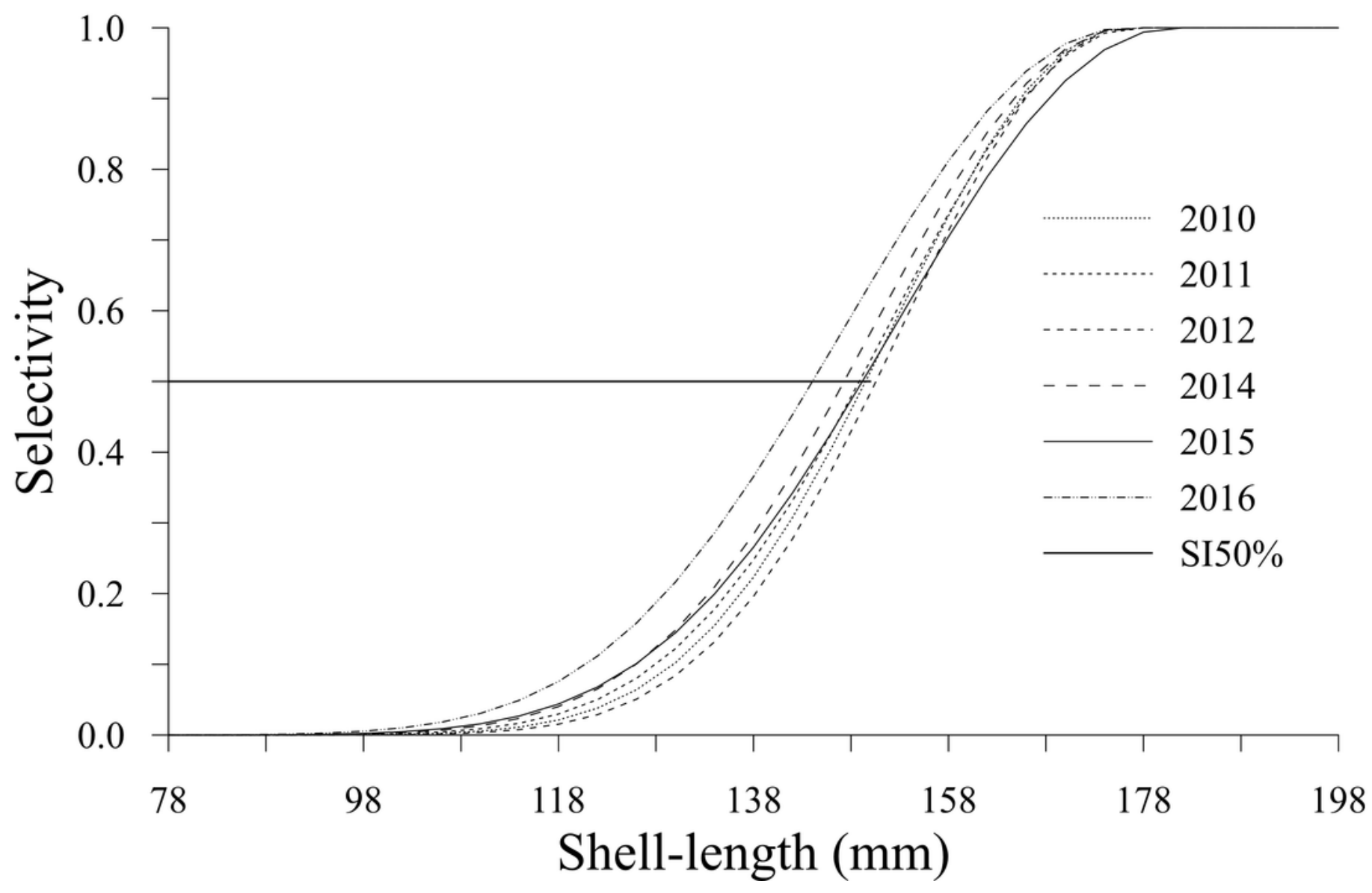


Figure 6

Harvest rate-at-shell length estimated for the geoduck clam Panopea globosa smaller than the minimum legal shell length of $130 \mathrm{~mm}$

A) time period from 2010-2012, and B) time period from 2014-2016. 

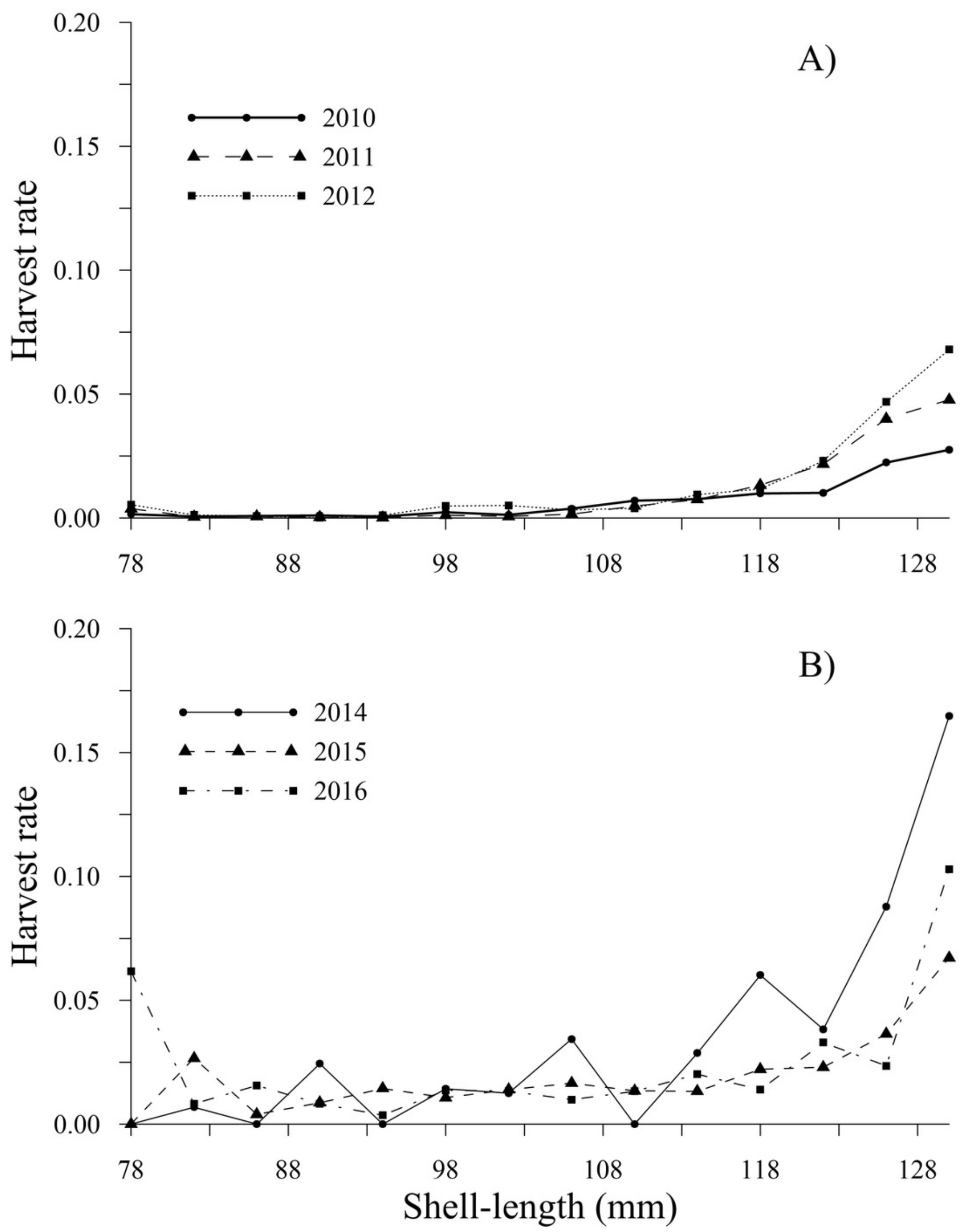
Figure 7

Harvest rate-at-shell length estimated for the geoduck clam Panopea globosa larger than minimum legal shell length of $130 \mathrm{~mm}$

A) time period from 2010-2012, and B) time period from 2014-2016. 


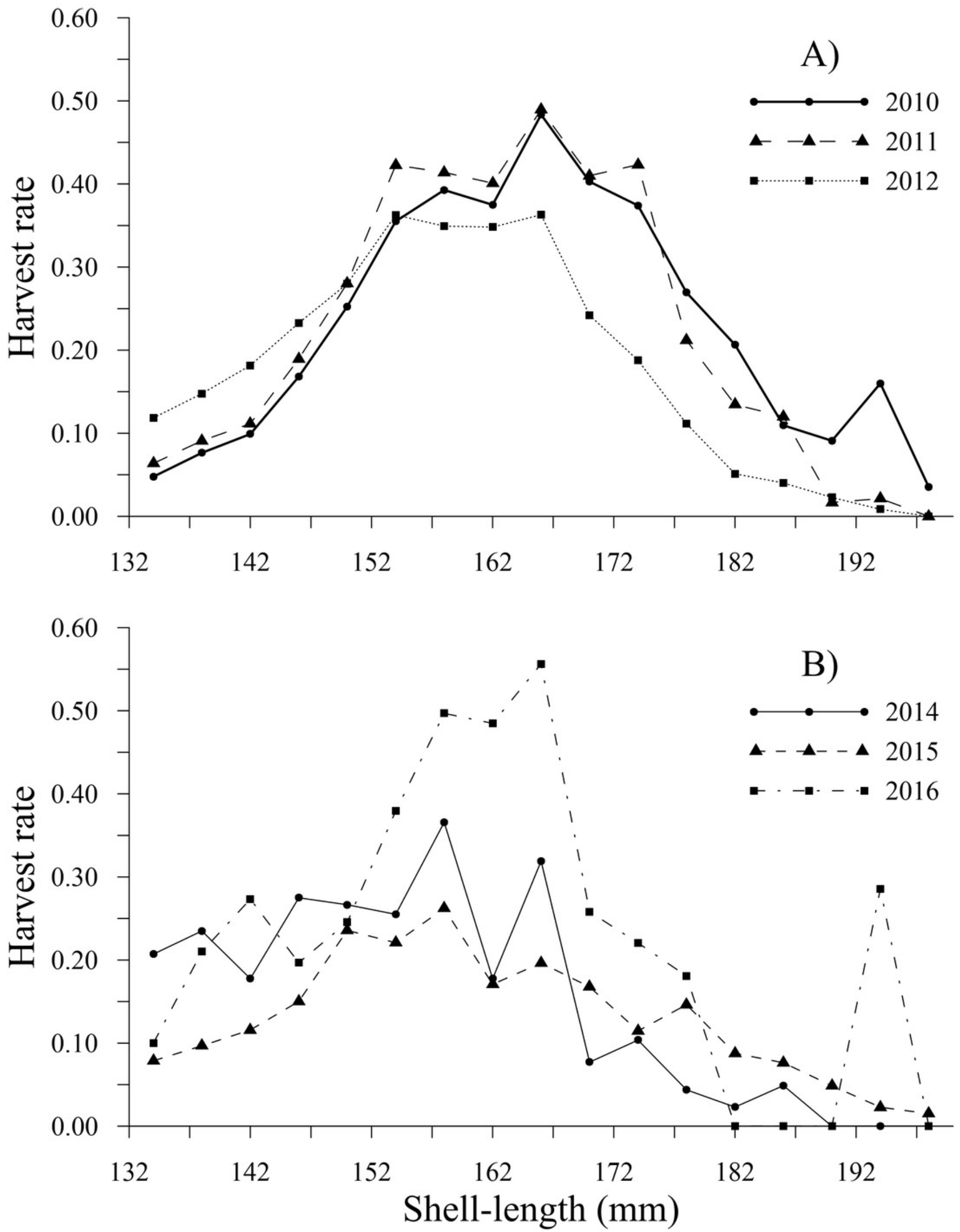


Figure 8

Total biomass-at-shell length estimated for the geoduck clam Panopea globosa in Puerto Peñasco, Sonora
A) time period from 2010-2012, and B) time period from 2014-2016. 

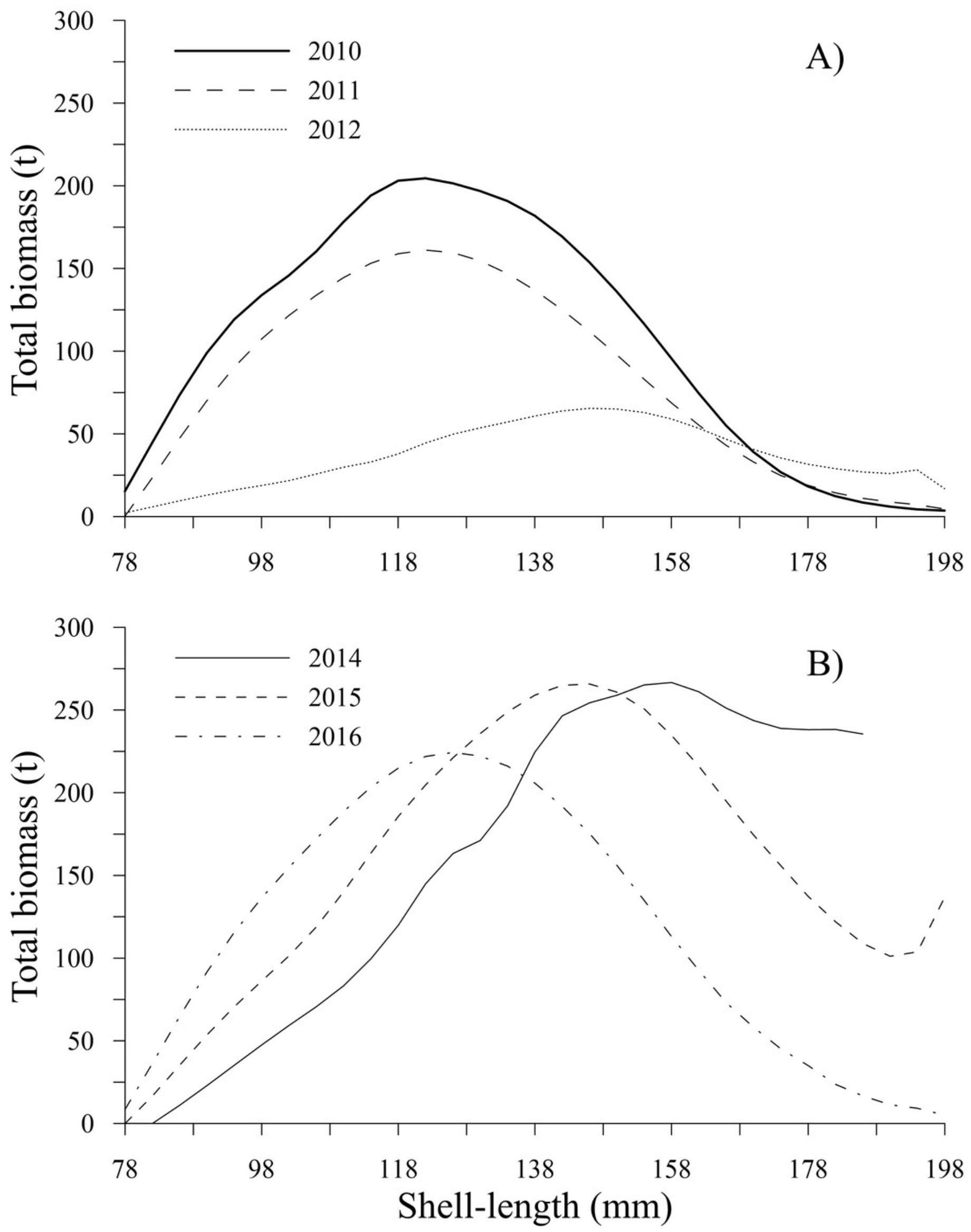
Figure 9

Vulnerable biomass-at-shell length estimated for the geoduck clam Panopea globosa in Puerto Peñasco, Sonora
A) time period from 2010-2012, and B) time period from 2014-2016. 

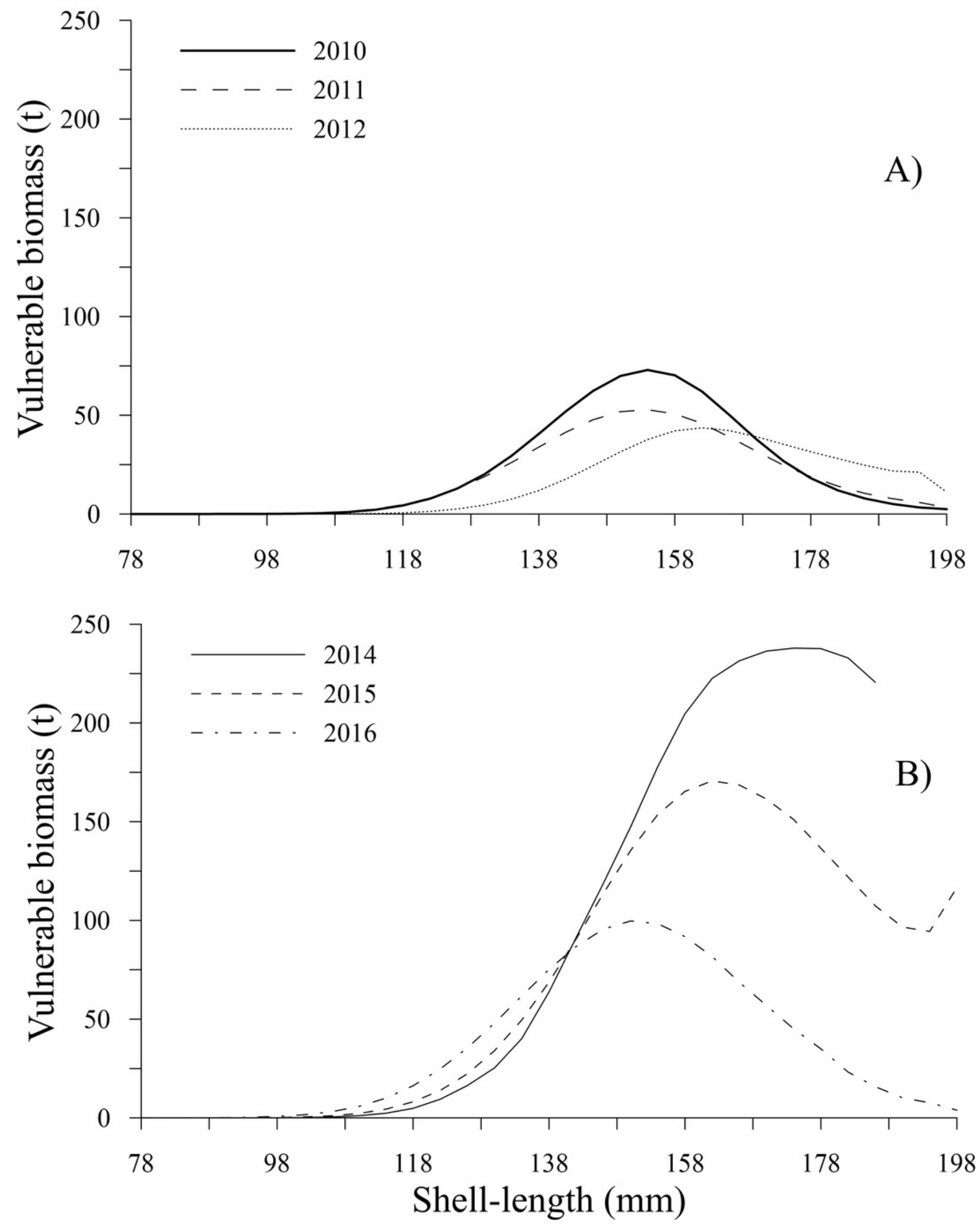


\section{Figure 10}

Spatiotemporal changes in the fishing area of the geoduck clam Panopea globosa from 2009 to 2016.

To find the coverage of a fishing area, the station positions were loaded into GIS software; the boundary stations were traced, and the enclosed areas were calculated $\left(\mathrm{km}^{2}\right)$ (OchoaAraiza et al., 2014, 2015). A) 2009, B) 2010, C) 2011, D) 2012, E) 2013, and F) 2014-2016. The figure was created and edited by Daniela Maldonado Enriquez (CIBNOR SC). 


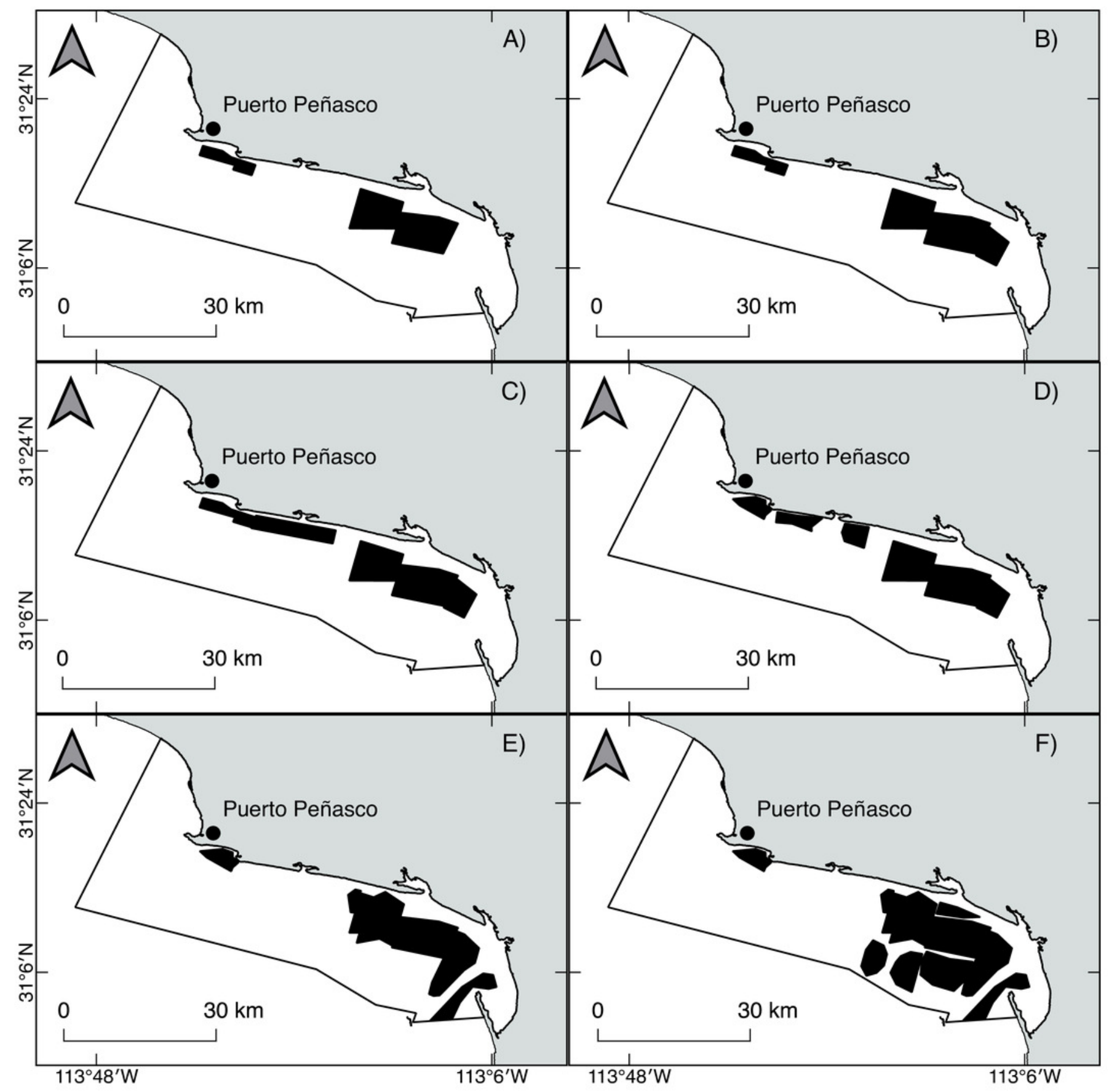

